UC-25 Metallurgy and Ceramics (TID-4500, 15th Ed.)

Contract No. W-7405-eng-92

DEVELOPMENT OF THORIUM-URANIUM-BASE

FUEL ALLOYS

by

Martin S. Farkas

Arthur A. Bauer

Ronald F. Dickerson

March 18, 1960

BATTELLE MEMORIAL INSTITUTE

505 King Avenue

Columbus 1, Ohio 


\section{DISCLAIMER}

This report was prepared as an account of work sponsored by an agency of the United States Government. Neither the United States Government nor any agency Thereof, nor any of their employees, makes any warranty, express or implied, or assumes any legal liability or responsibility for the accuracy, completeness, or usefulness of any information, apparatus, product, or process disclosed, or represents that its use would not infringe privately owned rights. Reference herein to any specific commercial product, process, or service by trade name, trademark, manufacturer, or otherwise does not necessarily constitute or imply its endorsement, recommendation, or favoring by the United States Government or any agency thereof. The views and opinions of authors expressed herein do not necessarily state or reflect those of the United States Government or any agency thereof. 


\section{DISCLAIMER}

Portions of this document may be illegible in electronic image products. Images are produced from the best available original document. 
TABLE OF CONTENTS

$\underline{\text { Page }}$

ABSTRACT • • . . . . . . . . . . . . . . . . . . . . . . 1

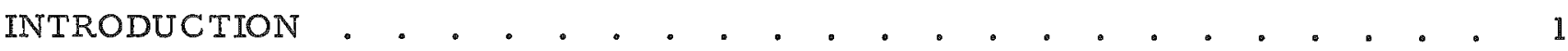

APPROACHES TO IMPROVED IRRADIATION AND CORROSION BEHAVIOR OF

THORIUM-URAIIUM-BASE ALLOYS .

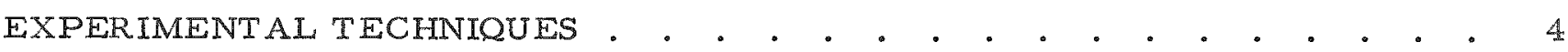

Alloy Preparation . . . . . . . . . . . . . . . . . . . 4

Fabrication and Heat Treatment . . . . . . . . . . . . . . . 6 .

Metallographic and X-Ray Diffraction Techniques . . . . . . . . .7

Hardness Measurements. . . . . . . . . . . . . . . . . 7

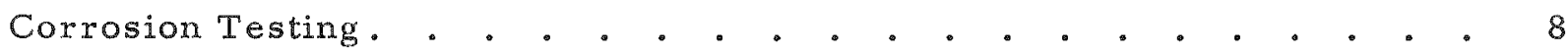

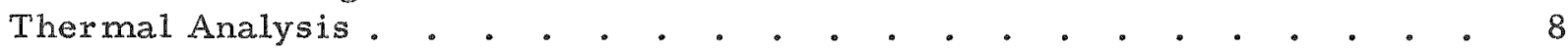

Density Measurements . . • . . • . . . . . . . . . . . 8

EXPERIMENTAL RESULTS AND DISCUSSION • • • • • • • • • •

Binary Thorium-Uranium Alloys . . . . . . . . . . . . . 9

Microstructure. . . . . . . . . . . . . . . . . . . 9

Cold Work and Recrystallization . . . . . . . . . . . . . 12

Hot Hardness . . . . . . . . . • . . . . . . . . . 17

Density Determinations . . . . . . . . . . . . . . . . 18

Ternary and Quaternary Thorium-Uranium Alloys . . . . . . . . 19

Microstructure. . . . . . . . . . . . . . . . . . . 19

Phase Studies . . . . . . . . . . . . . . . . . . 23

Hol Hardness . . . . . . . . . . . . . . . . . . . 23

Corrosion Results . • . . . . . . . . . . . . . . . . 25

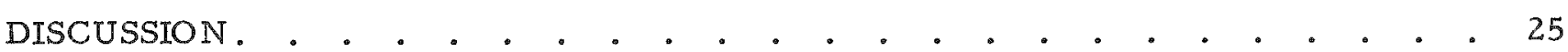

Binaxy Thorium-Uranium Alloys . . . . . . . . . . . . . . . 25

Ternary and Quaternary Thorium-Uranium Alloys . . . . . . . . . 28

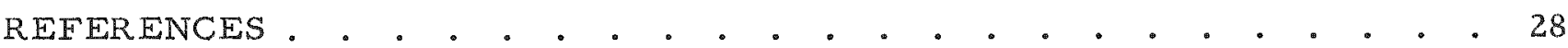




\title{
DEVELOPMENT OF THORIUM-URANIUM-BASE FUEL ALLOYS
}

Martin S. Farkas, Arthur A. Bauer, and Ronald F. Dickerson

\begin{abstract}
Thorium-uranium alloys u ere studied with the aim of developing alloys with improved irradiation behavior by control of microstructure. The effect of thorium purity, melting technique, hot and cold uorhing, and heat treatment on microstructure was investigated. The most significant microstructural differences occurred as a result of casting technique. The arc-melied alloys exhibited the most nearly ideal structure, that of a homogeneous dispersion of small-diameter uranium particles in a thorium matrix.
\end{abstract}

In addition, the rate of work hardening. recrystallization behavior, density, and hot hardness of thorium-uranium alloys were determined. As uranium content increases, the rate of work hardening increases. The recrystallization temperature of thorium was found to increase by over $100 \mathrm{C}$ when uranium is present.

Molybdenum, niobium, zirconium, and zirconium in conjunction with niobium were added to thorium-uranium with the aim of increasing irradiation resistance by stabilizing the gamma-uranium phase and/or improving the high-temperature strength of the alloy. It u'as found that small additions of molybdenum or niobium were effective in stabilizing the gamma-uranium phase, while zirconium was an effective hardener at temperatures up to $600 \mathrm{C}$.

Zirconium additions to thorium-uranium alloys ure effective in improving the $300 \mathrm{C}$ water corrosion resistance of thorium by a factor of two.

\section{INTRODUCTION}

The conservation and economic utilization of nuclear fuels leads to the consideration of breeder reactors for the generation of nuclear power. Breeding can be accomplished either by the uranium 238-plutonium 239 cycle or by the thorium 232-uranium 233 cycle. The theoretical breeding gain 10.03 for plutonium and 0.31 for uranium-233 at thermal energies), which is the number of excess neutrons available for the accumulation of a fuel species after allowing for the neutrons required to replace the fuel burned and the neutrons required to maintain the chain reaction, shows that breeding is a theoretical possibility regardless of the fuel cycle considered. However, not all of the excess neutrons produced during fission of the fuel are available for capture by the breeding material since a number will be absorbed by various components of a reactor. Consequently, when considering a reactor operating with the rmal or epithermal neutrons, it becomes obvious that the greatest possibility of achieving breeding lies with the thorium 232-uranium 233 cycle. 
Despite the distinct advantage offered by the thorium-uranium fuel cycle for breeding with thermal and epithermal neutrons, thorium-uranium-base fuels have received only slight consideration. This lack of interest and emphasis stems in part from the handling problems involved in the reconstitution of the fuel. Uranium-233 exhibits a high alpha activity. However, it is felt that if sufficient advantage could be demonstrated in fuel performance, as compared with uranium-base fuels, then this advantage might outweigh the disadvantages during fuel reprocessing.

The purpose of this research is to examine the properties and behavior of thorium-uranium-alloy fuels and to investigate the possibility of developing fuel alloys with improved properties, considering primarily the areas of improved irradiation and corrosion behavior. It is already known that thorium exhibits much greater resistance to radiation damage than uranium. Thorium exists in a face-centered-cubic crystal structure which is much less susceptible to irradiation embrittlement than either the orthorhombic alpha uranium structure or the body-centered-cubic structure of gammastabilized uranium alloys. Thorium, being cubic in structure and exhibiting no phase transformations at conceivable reactor operating temperatures, is essentially isotropic in nature and, consequently, undergoes none of the anisotropic growth and bumping and warping exhibited by uranium during irradiation and thermal cycling. It has also been demonstrated $(1)$ that thorium-uranium alloys resist swelling during irradiation to temperatures of about $600 \mathrm{C}$ at $1 \mathrm{a} / 0$ total burnup while the irradiation-swelling temperature for alpha uranium and alpha-uranium-phase alloys is about $400 \mathrm{C}$.

\section{APPROACHES TO IMPROVED IRRADIATION AND CORROSION BEHAVIOR OF THORIUM-URANIUM-B.ASE ALLOYS}

Thorium-uranium alloys exhibit a microstructure consisting of uranium particles dispersed in a thorium matrix. Thus the thorium acts as a containing and restraining matrix, and the damage due to fission fragments is localized in the uranium particles and the thorium immediately adjacent to the particles. In binary thorium-uranium alloys, it is believed that increased resistance to radiation damage can be obtained if:

(1) The uranium particle size is small enough that fission fragments produced in the uranium lodge almost entixely in the thorium, restricting the irradiation damage preferentially to the thorium, which is more resistant to such damage.

(2) The uranium particles are distributed randomly within the thorium grains and not at the grain boundaries, which would provide a mechanism and site for rare-gas diffusion and agglomeration.

(3) The uranium is kept in particle form, since once it becomes continuous it will act as the matrix, and uranium irradiation behavior will be observed.

(1) References at end. 
The relationship between uranium particle size and the probable fission-fragment distribution between the thorium matrix and uranium particle has been developed from geometrical considerations and is given as follows:

$$
P=\frac{a}{d}\left[150-50\left(\frac{a}{d}\right)^{2}\right],
$$

where $P$ is the probability, in per cent, that the fission fragments will lodge in the thorium matrix, $a$ is the fission-fragment range, and $d$ is the diameter of the uranium particle under consideration. If one assumes that the fission fragments have an average range equivalent to a $4-\mathrm{Mev}$ alpha particle, then their range in uranium is $6.46 \mu$. The distribution of fission fragments as a function of uranium particle size for this range is shown in Figure 1. It can be seen that, if the uranium particle diameter is less than the fission-fragment range, $6.46 \mu$, then all of the fission fragments should lodge in the thorium. This is the desired condition.

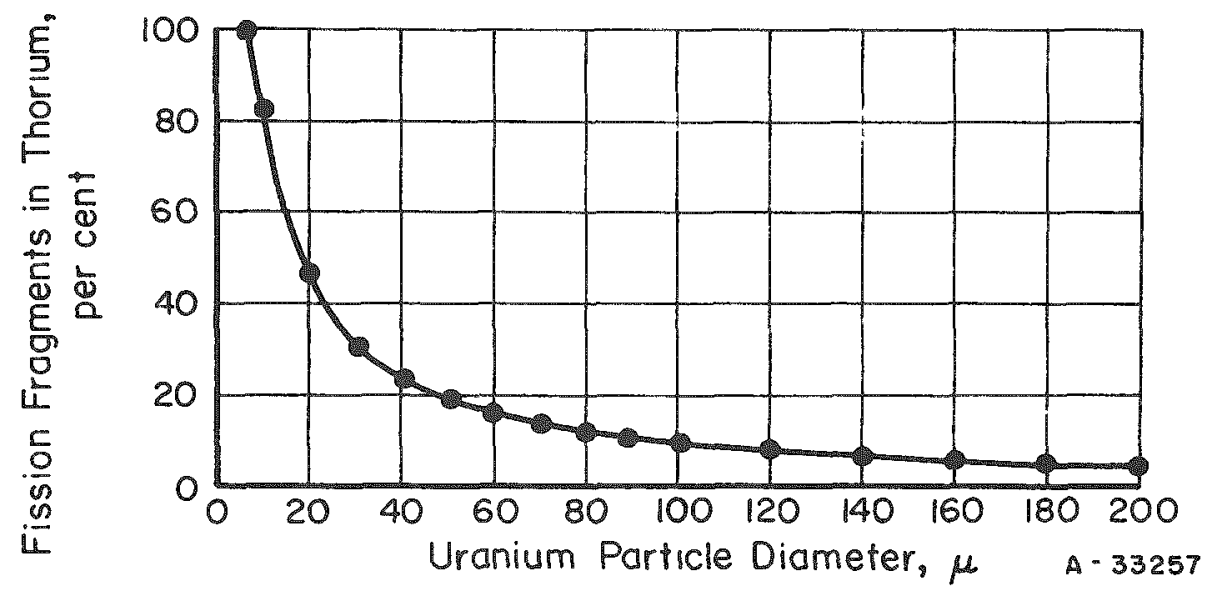

\section{FIGURE 1. PROBABLE DISTRIBUTION OF FISSION FRAGMENTS IN THORIUM MATRIX AS A FUNCTION OF URANIUM PARTICLE SIZE IN A THORIUM-URANIUM FUEL ALLOY}

In addition to microstructural control, alloying with low-neutron-cross-section elements provides a means of improving irradiatın performance of thorium-uranium alloys. Three approaches have been considered here:

(1) Alloying to increase the strength of the thorium matrix and, hence, its resistance to radiation swelling. Zirconium strengthens thorium by solid-solution hardening and was therefore evaluated as an addition.

(2) Alloying to stablize gamma-uranium-phase particles which exhibit improved irradiation behavior and fission-gas retention as compared with alpha uranium. Niobium and molybdenum additions were employed because neither is soluble in thorium, and both will stabilize the gamria-uranium phase at low concentrations. 
(3) Alloying to increase the strength of the thorium matrix and to stabilize gamma-uranium particles. To study this case additions of both zirconium and niobium to thorium-uranium were used. They are:

Attempts to improve corrosion resistance have been based on two approaches.

(1) Alloying and heat treating to produce a continuous corrosionresistant phase surrounding the thorium. This involved alloying with zirconium to produce the uranium-zirconium delta phase as the uranium phase in the alloy and then heat treating to have this phase form a grain-boundary network.

(2) Alloying to produce a more stable oxide layer on the thorium and one which would act as a barrier to further oxygen penetration. This second approach involved alloying with elements that form stable oxides which may be soluble in $\mathrm{ThO}_{2}$. These additions include cerium, lanthanum, ruthenium, titanium, and yttrium.

\section{EXPERTMENTAL TECHNIQUES}

Binary iodide and Ames thorium-uranium alloys were prepared by arc and induction melting and casting into bar form. The bars were hot rolled and subsequently cold rolled to $20,60,80$, and 90 per cent reductions. Hot-hardness specimens were obtained from hot-rolled material. Recrystallization studies were performed on specimens removed from the cold-rolled material. Metallographic examination of the as-cast, hot-rolled, cold-rolled, and heat-treated alloys was performed.

Ternary and quaternary thorium-uranium alloys were arc melted into wire bars, and specimens for hot-hardness tests and thermal analysis were removed from the hotrolled bar, after which the remaining material was cold rolled to a 20 per cent reduction. Specimens for heat-treating and metallographic studies were removed from the cold-rolled plate.

\section{Alloy Preparation}

Spectrographic analyses of the Ames and iodide thorium used in this investigation are listed below:

Ames thorium

Iodide tho rium

\begin{tabular}{|c|c|c|c|c|c|c|c|c|c|c|}
\hline \multicolumn{11}{|c|}{ Analysis, ppm } \\
\hline Al & $\mathrm{B}$ & $\mathrm{Be}$ & $\mathrm{Ca}$ & $\mathrm{Cr}$ & $\mathrm{Cu}$ & $\mathrm{Fe}$ & $\mathrm{Mg}$ & $\mathrm{Ni}$ & $\mathrm{Si}$ & $\mathrm{Zr}_{\mathrm{r}}$ \\
\hline 10 & 0.5 & 50 & 10 & 10 & 2 & 30 & 1 & 5 & 10 & 150 \\
\hline 10 & 0.5 & -- & 5 & -- & 2 & 5 & $<1$ & 2 & 13 & $<3$ \\
\hline
\end{tabular}


All other metallics were below the limit of detection. Since the iodide-thorium analysis was performed on only one of several batches received from the producer, it must be considered only as typical. No analyses were performed for carbon and nitrogen; however, these analyses were obtained latex on thorium-10 w/o uranium alloys.

In order to avoid introduction of impurities, charges were prepared immediately prior to meling. Charge preparation consisted of pickling the Ames thorium and iodide zirconium; electropolishing was utilized to clean the uranium. The molybdenum, niobium, and iodide thorium needed no special preparation.

The binary alloys were prepared with biscuit uranium and two grades of thorium. Ames and iodide. Vacuum-induction heats of 5, 10, and $20 \mathrm{w} / 0$ uranium were melted in zirconia crucibles and cast into graphite molds. Bars 5 in. long by $1 / 2$ in. in diameter were obtained. Arc melts of 5, 10, 15, and 20 w/o uranium containing both grades of thorium were also prepaxed. Each alloy was melted at least eight times in a tungstentip arc furnace and was then cast into a finger bar 3 in. long by $1 / 2 \mathrm{in}$. in diameter.

Wet-chemical and vacuum-fusion analyses of the cast thorium-10 w/o uranium alloys are presented below:

Induction-melted iodide thorium Induction-melted Ames thorium. Arc-melted iodide thorium Arc-melted Ames thorium

\begin{tabular}{ccc}
\multicolumn{3}{c}{ Analysis, ppm } \\
\hline Carbon & Nitrogen & Oxygen \\
\cline { 2 - 3 } 120 & 10 & 1660 \\
770 & 80 & 1560 \\
190 & 90 & 680 \\
710 & 90 & 1590
\end{tabular}

Spectrographic analyses of the induction-melted $10 \mathrm{w} / \mathrm{o}$ uranium alloys also showed that both the Ames and iodide alloys contained $100 \mathrm{ppm}$ zirconium, indicating that the iodide alloy absorbed zirconium from the zirconia melting crucible. Presumably the crucible is the source of high oxygen content in the induction-melted iodide alloy, as compared to the arc-melted iodide alloy.

It can be seen that the carbon content of the Ames material was high compared with that of the iodide material. Oxygen was the other contaminant which was significantly higher in the Ames material than in the iodide thorium.

The ternary and quaternary alloys were prepared using iodide thorium, biscuit uranium, crystal-bar zirconium, high-purity molybdenum, and triple-sintered niobium. The arc-melting techniques described above were used to obtain finger bars. The compositions prepared are listed below:

Thorium-10 w/o uranium- $1.5 \mathrm{w} / \mathrm{o}$ molybdenum

Thorium-20 w/o uranium-3 $\mathrm{w} / 0$ molybdenum

Thorium-10 w/o uranium-2 w/o niobium

Thorium-20 w/o uranium-4 w/o niobium.

The above alloys have compositions designed to produce gamma-phase uranium particles in a thorium matrix. 
Thorium- $10 \mathrm{w} / \mathrm{o}$ uranium-10 w/o zirconium

Thorium-20 w/o uranium $-20 \mathrm{w} / 0$ zirconium

Thorium-25 w/o uranium-25 w/o zirconium.

The above compositions were designed to produce a strengthened thorium matrix for improved irradiation behavior and a microstructure containing the delta uraniumzirconium phase, which, if continuous throughout the alloy, would possibly improve corrosion resistance.

Thorium-10 w/o uranium-5 w/o zirconium-2 w/o niobium Thorium-15 w/o uranium-7.5 w/o zirconium-3 w/o niobium

Thorium-20 w/o uranium-10 w/o zirconium-4: w/o niobium

Thorium-10 w/o uranium-10 w/o zirconium-2 w/o niobium

Thorium-15 w/o uranium-15 w/o zirconium-3 w/o niobium

Thorium-20 w/o uranium-20 w/o zirconium-4 w/o niobium.

Compositions listed above were chosen in an attempt to provide an alloy that contained both gamma-stabilized uranium particles and a strengthened thorium phase for improved irradiation resistance. Improved corrosion resistance was also sought from the standpoint of forming a delta-phase envelope around the thorium grains.

Additional compositions were investigated only from the standpoint of corrosion resistance and are listed under the section entitled "Corrosion Results".

\section{Fabrication and Heat Treatment}

After casting, the binary alloys and the molybdenum-and niobium-containing alloys were hot rolled at $1500 \mathrm{~F}$ to 0.2 -in. flats. The other ternary and quaternary alloys were hot rolled to $0.2-\mathrm{in}$. at $1800 \mathrm{~F}$; however, the thorium-10 w/o uranium$5 \mathrm{w} / 0$ zirconium $-2 \mathrm{w} / 0$ niobium and the thorium-10 w/o uranium-10 w/o zirconium$2 \mathrm{w} / \mathrm{o}$ niobium alloys cracked severely. Subsequent hot rolling of additional bars of these latter two compositions was successful at $1500 \mathrm{~F}$.

The binary alloy plates were cold reduced by $20,60,80$, and 90 per cent. After 80 per cent reduction edge cracking was evidenced on all except the arc-melted iodidethorium alloys containing 5, 10, and 15 w/o uranium. After 90 per cent cold reduction, all of the binaries showed at least slight edge cracking, although none was badly cracked.

The ternary and quaternary alloys were cold reduced 20 per cent; however, edge cracking was observed in the thorium-uranium-zirconium alloys and two of the quaternaries.

High-temperature heat treatments ( $800 \mathrm{C}$ and above) were performed in a vacuum furnace maintained at a pressure of $10^{-4} \mathrm{~mm}$ of mercury or less.

Low-temperature recrystallization heat treatments were performed by suspending specimens in a lead bath at the required temperature. After the desired length of time had elapsed, the specimens were water quenched. 
Metallographic and X-Ray Diffraction Techniques

Metallographic preparation of thorium-uxanium alloys is not a well-developed art, and considerable effort is involved in developing suitable microstructures. The methods developed in this investigation have proven most satisfactory; however, choice of a proper etchant is still subject to trial and error.

Specimens were mounted in Bakelite and wet ground through 600-grit paper. Vibratory polishing was employed, using Linde $B$ abrasive on Microcloth. Either water or a 10 volume per cent oxalic acid solution was used as a suspension medium for the abrasive. The etchants that were used are listed below:

(1) 5 volume per cent sodium hydroxide at $6 \mathrm{v}$ dc for 60 to $160 \mathrm{sec}$

(2) $200 \mathrm{~cm}^{3}$ of ethyl alcohol and $20 \mathrm{~cm}^{3}$ of perchloric acid applied at 35 to $70 \mathrm{v}$ de for 2 to $5 \mathrm{sec}$

(3) $200 \mathrm{~cm}^{3}$ of acetic acid and $20 \mathrm{~cm}^{3}$ of perchloric acid applied at $35 \mathrm{v}$ dc for 1 to $5 \mathrm{sec}$

(4) $100 \mathrm{~cm}^{3}$ of glycerin, $100 \mathrm{~cm}^{3}$ of acetic acid, and $10 \mathrm{~cm}^{3}$ of nitric acid applied at $35 \mathrm{v}$ de for $1 / 2$ to $3 \mathrm{sec}$

(5) $100 \mathrm{~cm}^{3}$ of glycerin, $50 \mathrm{~cm}^{3}$ of acetic acid, and $5 \mathrm{~cm}^{3}$ of nitric acid applied at $6 \mathrm{v}$ dc for 5 to $30 \mathrm{sec}$.

The binary alloys were etched in one of the first four solutions mentioned. The ternary and quaternary alloys were etched in Solutions (2), (3), or (5).

In some cases, chemical etchants proved unsatisfactory and vacuum-cathodic etching techniques were employed. These techniques were usually highly successful, particularly with the binary alloys. Excellent oxide-particle retention and phase delineation was obtained. However, since a large number of specimens were being examined, chemical etching was the preferred method for preparation.

Samples to be used for $\mathrm{X}$-ray diffraction examination were wet ground to conical form. They were then electropolished in a $\mathrm{ZrCl}_{2}-\mathrm{AlCl}_{3}$ solution and mounted in a $57.3-$ $\mathrm{mm}$ Debye camera with the X-ray beam impinging on the tip of the cone. Filtered iron radiation was used for examination.

\section{Hardness Measurements}

Room-temperature hardness values were obtained on mounted and polished specimens as part of the recrystallization studies. Vickers diamond-pyramid hardness readings were taken using either $2-1 / 2$ - or $10-\mathrm{kg}$ loads. 
Hot-hardness values were obtained on polished specimens using a Vickers indente $x$ and a load of $730 \mathrm{~g}$. Values were generally obtained at room temperature and $200,400,500,600,800$, and $900 \mathrm{C}$. Specimens were heated in a vacuum-resistance furnace, and the hardness indentations were made in situ. Measurements were performed after indentations had been made at the temperatures of interest and after the specimens had cooled and been removed from the furnace.

\section{Corrosion Testing}

The ternary and quaternary alloys were corrosion tested in degassed and deionized water at $200 \mathrm{C}$. Corrosion specimens, obtained from hot-rolled flat plates, measured approximately $3 / 8$ by $3 / 8$ by $0.2 \mathrm{in.}$ They were wet ground on $240-\mathrm{grit}$ paper, heat treated, and lightly ground again to remove any oxide that was formed. The double grinding was performed so that the surfaces would retain as little cold work as possible, since cold working is known to have a deleterious effect on the corrosion resistance of thorium alloys.

The specimens were weighed, measured, and placed on test. Examination of the alloys was made after exposures of $24,72,168,336$, and $504 \mathrm{hr}$. This examination consisted of a determination of the weight change and a visual inspection to determine the type of attack and the surface condition. Weight change per unit area was calculated on the basis of the original surface area of the uncorroded specimen.

\section{Thermal Analysis}

Time-temperature thermal analyses were performed on small (less than 1/8-in. cube) specimens, which were spot welded to platinum-platinum $10 \mathrm{w} / 0$ rhodium thermocouples. The specimens were heated in a vacuum-induction furnace at a rate of $400 \mathrm{C}$ per min, the heating curve being recorded. Phase changes were indicated by changes in slope of the heating curve. The values recorded were an average of at least two determinations. Although the heating rate was fast, it is felt that superheating was not significant as very small specimens were used and reproducible arrests were obtained. Cooling-curve data were not considered, as comparison with heating curves showed that marked supercooling occurs in the alloys studied.

\section{Density Measurements}

Densities of thorium-uranium alloys were determined by precisely measuring the dimensions of rods reduced 80 per cent by cold swaging and then calculating the volume. The rods were then weighed and the density calculated.

Thorium densities were obtained by the displacement method on 60 per cent coldreduced plate. 


\section{EXPERIMENTAL RESULTS AND DISCUSSION}

As a result of the program, data were obtained which permit a description of the effects of casting, fabrication, and heat-treatment variables on the structure of thorium-uranium alloys. The effect of uranium composition on hot hardness and density was determined and the cold working and recrystallization behavior of the binary alloys were studied.

Ternary and quaternary additions to the binary alloys and their effect on constitution, corrosion resistance, and hot hardness were also investigated.

The thorium-uranium constitutional diagram is reproduced for reference purposes in Figure 2.

Binary Thorium-Uranium Alloys

\section{Microstructure}

The only definite difference in microstructure between alloy material prepared from Ames and from iodide thorium was in the amount of thorium oxide present. The alloys prepared from Ames thorium contained considerably more oxide inclusions, reflecting the higher oxygen content of the thoxium used in the alloy preparation.

The technique of casting had a much more pronounced effect on microstructure, not only directly aftex casting but after subsequent working. This effect was not too noticeable in the $5 \mathrm{w} / 0$ uranium alloy, which showed very little evidence of uranium precipitation. Apparently a considerable portion of the uranium is retained in solid solution in the tho rium due to fairly rapid solidification and cooling of the cast bars. $\mathrm{Up}$ to $10 \mathrm{w} / \mathrm{o}$ uranium is soluble in alpha thorium at elevated temperatures (Figure 2), although this solubility decreases to less than $1 \mathrm{w} / 0$ near room temperature. The uranium that does precipitate in the $5 \mathrm{w} / 0$ uranium alloy occurs as a very finely dispersed phase (Figure 3a).

In the thorium-10 w/o uranium alloys, arc-melted material exhibited a nearly uniform dispersion of random uranium particles (Figure $3 \mathrm{~b}$ ). In the induction-melted material, the uranium tended to concentrate at grain boundaries (Figure 3c). Furthermore, the grain-boundary-precipitated uranium tended to form a continuous grainboundary phase. This became more obvious at higher uranium concentrations. In the $20 \mathrm{w} / 0$ uranium alloy the uranium phase at the grain boundary, as can be seen in Figure $3 \mathrm{~d}$, was quite heavy and continuous in a majority of the grain boundaries. One could expect such a structure to exhibit properties similar to the continuous alphauranium matrix phase.

With increasing amounts of uranium, the arc-melted alloys also showed increasing amounts of uranium (Figures $3 \mathrm{e}, 3 \mathrm{f}$, and $3 \mathrm{~g}$ ). However, while the uranium particles increased in size and there was a tendency for particles to appear in grain boundaries, the uranium phase was not continuous, and a fairly random distribution of particles was maintained. 


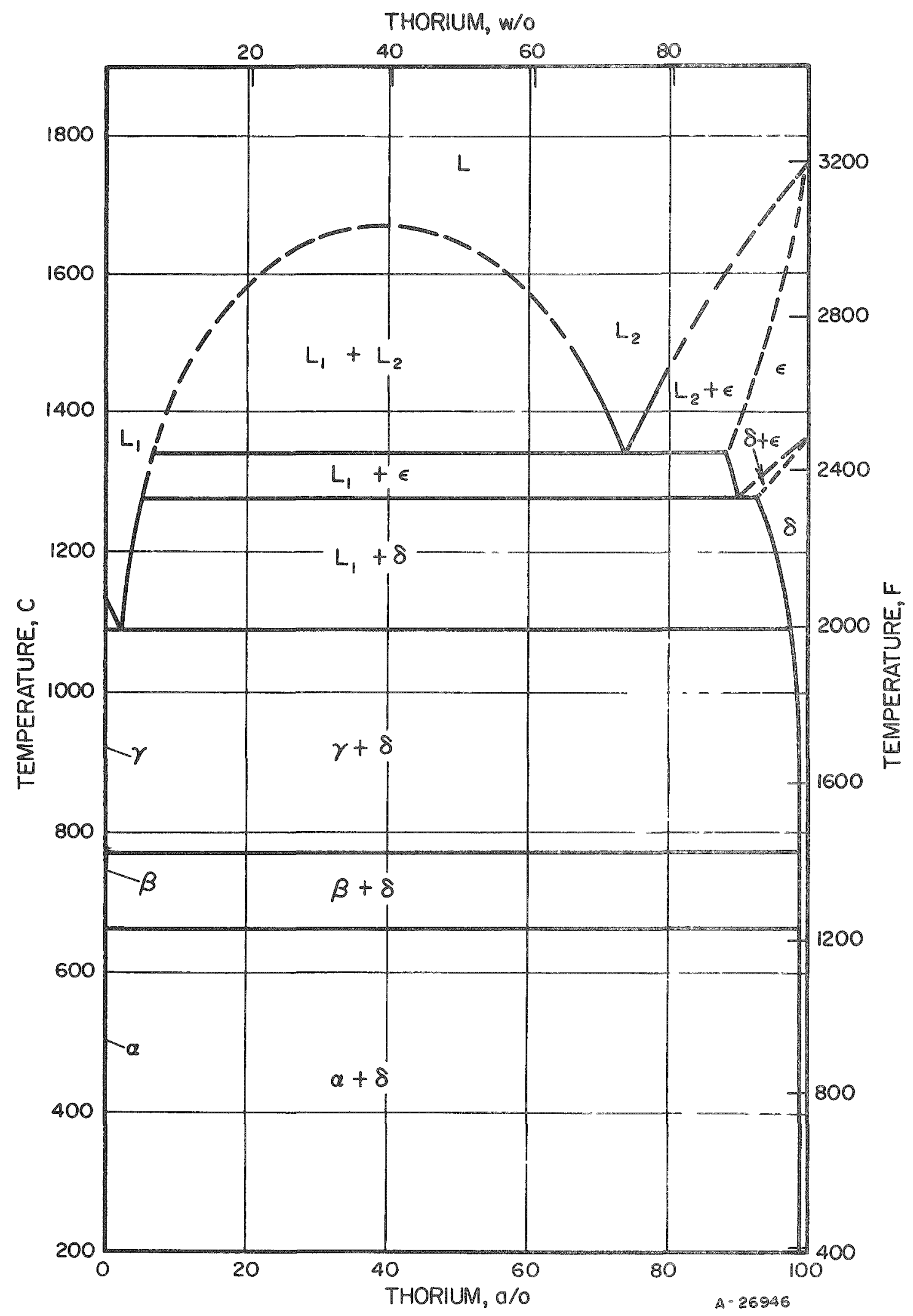

FIGURE 2. THORIUM-URANIUM CONSTITUTIONAL DIAGRAM 
11

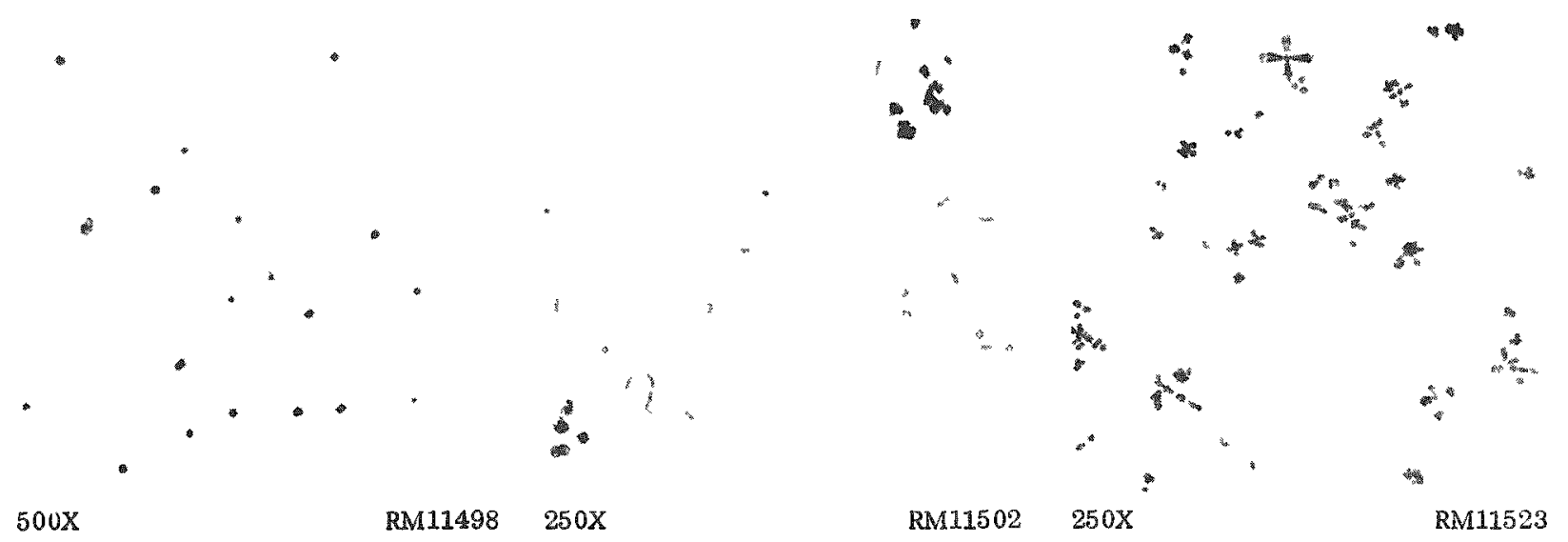

a. 5 w/o Uranuum As Arc Cast

b. $10 \mathrm{w} / 0$ Uranum As Arc Cast

c. 10 w/o Uranum As Induction Cast

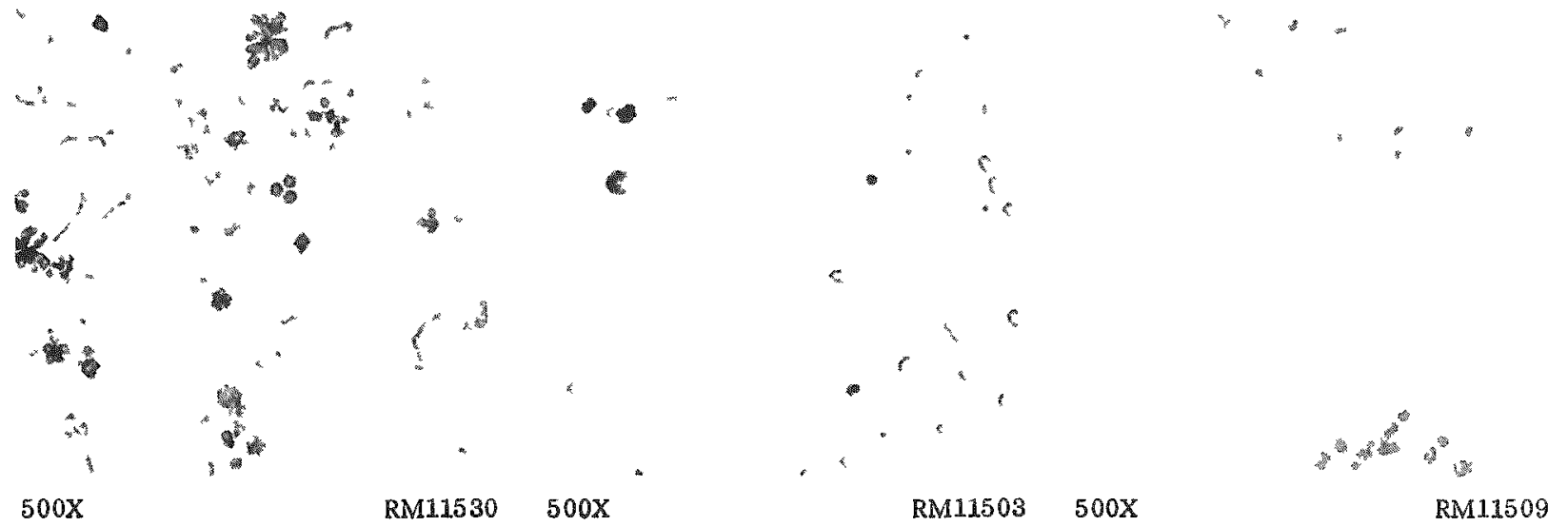

d. 20 w/o Uranium As Induction Cast e. 10 W/o Uranium As Arc Cast

f. $15 \mathrm{~W} / \mathrm{O}$ Uranum As Arc Cast

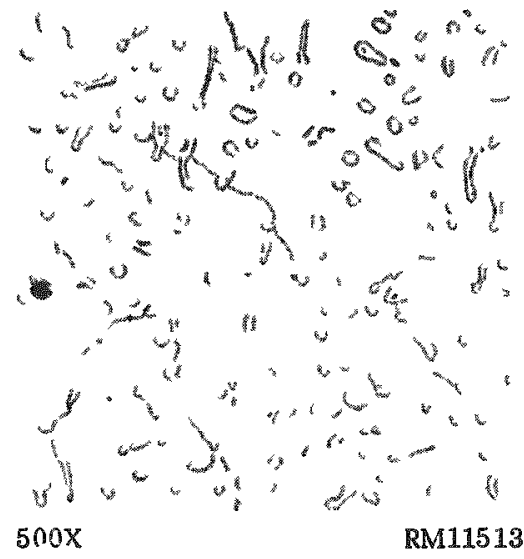

g. 20 W/o Uranum As Arc Cast

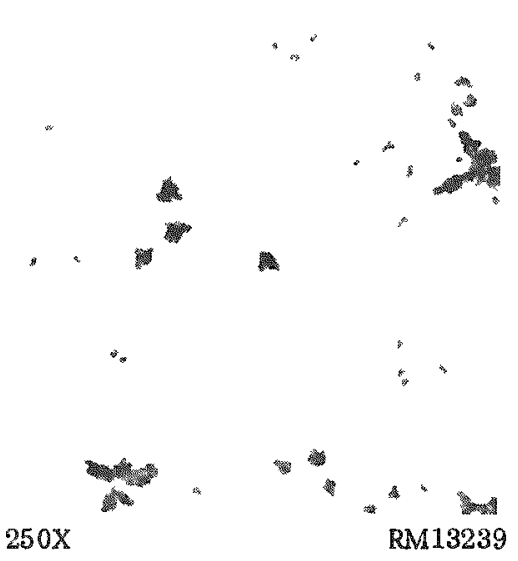

h. $10 \mathrm{w} / \mathrm{o}$ Uranium Induction Cast, Heated $1 \mathrm{Hr}$ at $1000 \mathrm{C}$, and Water Quenched

FIGURE 3. MICROSTRUCTURES OF CAST IODIDE THORIUM-URANIUM ALLOYS

At $250 \mathrm{X}$, the critucal uranium particle diameter of $6.46 \mu$ is $0.062 \mathrm{in}$. , at $500 \mathrm{X}$ it $1 \mathrm{~s} 0.125 \mathrm{in}$. 
The differences in microstructure between arc- and induction-cast material can be attributed to the different cooling rates employed in the two casting processes. The arc-cast material was melted and cooled on a water-cooled copper hearth. The cooling rate was rapid and appaxently produced a sequence of events such that, as the melt supercooled, the uranium segregated to form liquid pools which were then entrapped by the solidifying thorium. Subsequent cooling was sufficiently rapid that the uranium soluble in thorium at elevated temperatures was essentially retained in thorium solid solution. Induction-melted material, which was cast into carbon crucibles, underwent a slower and more nearly equilibrium solidification and cooling process. As the melt solidified, thorium grains formed which reject the uranium-rich phase. This uranium phase thus appeared at the grain boundaries of the thorium grains. Additional grainboundary uranium precipitation from thorium solid solution could have occurred during subsequent cooling to room temperature.

It was found possible to eliminate a major portion of the uranium grain-boundary precipitate in the induction melted thorium $-10 \mathrm{w} / 0$ uranium alloy by heat treating at $1000 \mathrm{C}$ and water quenching. The results of this heat treatment are shown in Figure $3 \mathrm{~h}$. It can be seen that the uranium grain-boundary concentration was less pronounced as a result of solution of uranium in the thorium. However, the uranium particles still tended to reside at grain boundaries.

Cold-and hot-worked structures of thorium-uxanium alloys were found to be essentially determined by the cast structure. If the cast structure contained a random dispersion of uranium particles, working did not appreciably alter this, although large reductions did cause elongation of the particles. If the cast structure contained uranium at the grain boundaries, working emphasized the already elongated particles, and a uranium stringered structure resulted. Thus stringering was more pronounced in the induction-cast and in the high-uranium alloys.

Hot working the cast 1/2-in. -diameter bars at $1500 \mathrm{~F}$ to 0.2 -in. flat plates (approximately a 40 per cent reduction in area) did not significantly alter the as-cast structure of the alloys. Some slight additional precipitation of uranium may have occurred as a result of heating to the temperature of worling. However, if it did, the uranium apparently precipitated on the particles already present in the structure.

The effect of subsequent cold work is illustrated by the structures show in Figure 4. Arc-and induction-cast thorium-10 w/o uranium-alloy structures after 20 and 80 per cent cold reductions appear in Figures 4 a through 4 d. The induction-cast alloys exhibited much more pronounced elongation or stringering of uranium particles. However, when the uranium content was increased to $20 \mathrm{w} / \mathrm{o}$ (Figure $4 \mathrm{e}$ ), the arc-cast alloy also exhibited a decided stringered structure. Elongation of uranium particles was also more evident in the $10 \mathrm{w} / 0$ uranium alloy after a 90 per cent cold reduction. (Figure $4 \mathrm{f}$ ).

Cold Work and Recrystallization

The effect of cold work on the hardness of thorium-uranium alloys is recorded in Table 1. Comparison of the $10 \mathrm{w} / 0$ uranium alloys shows that alloys prepared from Ames thorium were harder and work hardened more rapidly than alloys prepared from iodide thorium. This higher hardness apparently was a result of the higher carbon content of the Ames thorium. The arc-melted iodide alloy was also harder than its companion induction-melted alloy. This higher hardness is believed to reflect retention of 


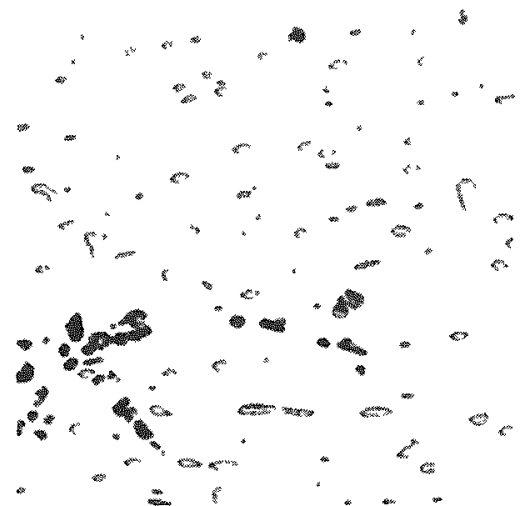

$750 \mathrm{X}$
$\mathrm{RM} 12179 \quad 750 \mathrm{X}$

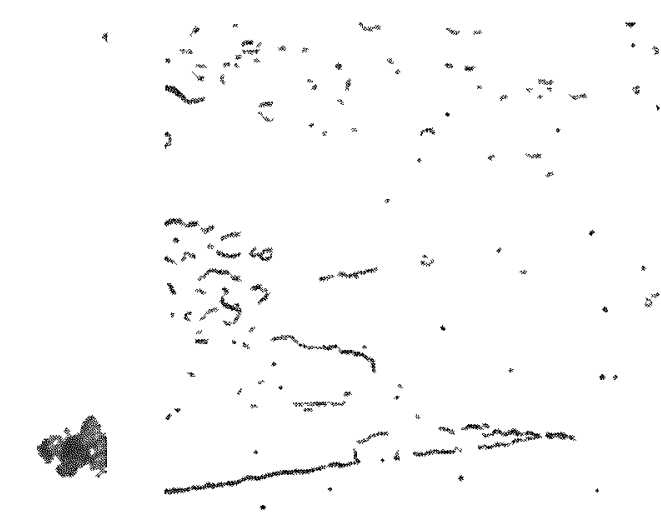

a. 10 w/o Uranium Arc Cast and Cold Reduced 20 per Cent b. $10 \mathrm{w} / \mathrm{o}$ Uranium Induction Cast and Cold Reduced 20 Per Cent

$750 \mathrm{X}$

RM12470

c. $10 \mathrm{w} / \mathrm{o}$ Uranium Arc Cast and Cold Reduced 80 Per Cent

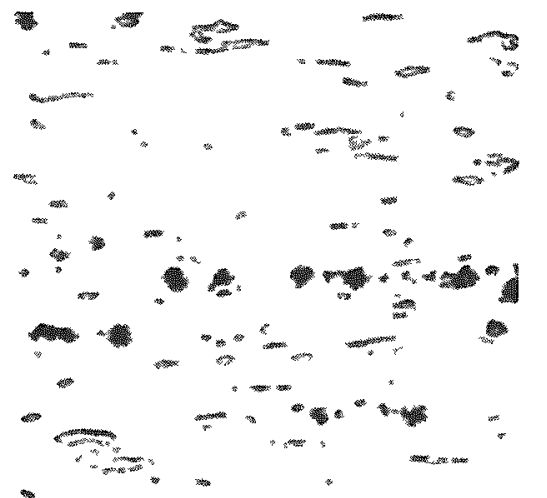

$750 \mathrm{X}$
RM13467

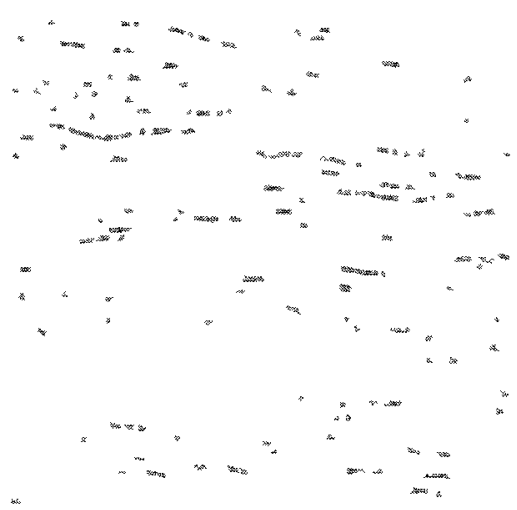

$750 x$
RM12376

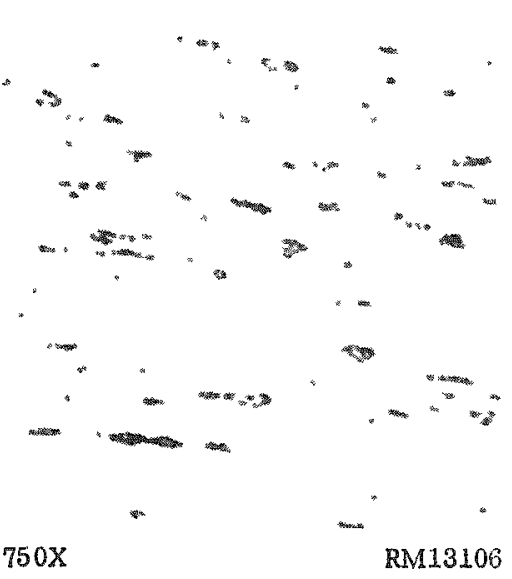

f. $10 \mathrm{w} / \mathrm{o}$ Uramiun Induction Cast and Cold Reduced 90 Per Cent

\section{d. 10 w/o Uranium Induction Cast and Cold Reduced 80 Per Cent}

e. $20 \mathrm{w} / \mathrm{o}$ Uranium Arc Cast and Cold Reduced 20 Per Cent

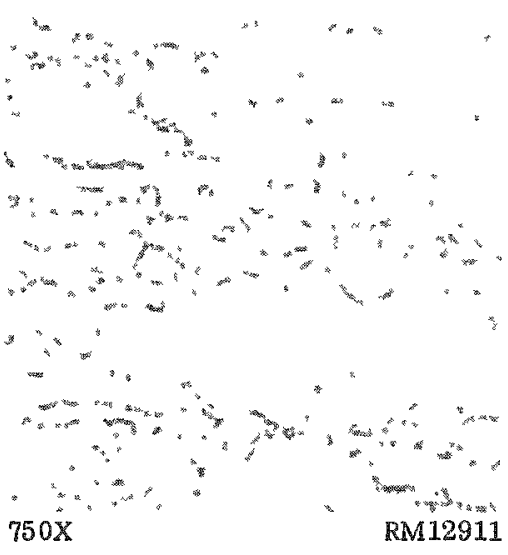

h. 10 w/o Uranium Arc Cast, Cold Reduced 80 Per Cent, and Annealed 1 Week at $800 \mathrm{C}$

FIGURE 4. LONGITUDINAL MICROSTRUCTURES OF WORKED IODIDE THORIUM-URANIUM ALLOYS

At $750 \mathrm{X}$, the critical particle diameter is 0.19 in. 
uranium in thorium solid solution during arc casting to produce solid-solution hardening; the more slowly cooled induction-cast alloy rejected uranium while cooling to room temperature and, consequently, was softer.

TABLE 」. THE EFFECT OF COLD WORK ON HARDNESS OF THORIUM-URANIUM ALLOYS

\begin{tabular}{|c|c|c|c|c|c|c|c|}
\hline \multirow{3}{*}{$\begin{array}{l}\text { Uranium } \\
\text { Content } \\
\text { (Balance Thorium), } \\
\text { w/o }\end{array}$} & \multirow{3}{*}{$\begin{array}{c}\text { Type of } \\
\text { Thorium Used }\end{array}$} & \multirow{3}{*}{$\begin{array}{l}\text { Melting } \\
\text { Method }\end{array}$} & \multicolumn{5}{|c|}{ Vickers Hardness Number (10-Kg Load) } \\
\hline & & & \multirow{2}{*}{$\begin{array}{c}\text { Hot } \\
\text { Rolled }\end{array}$} & \multicolumn{4}{|c|}{ Cold Reduced Percentage Shown } \\
\hline & & & & 20 & 60 & 80 & 90 \\
\hline 10 & Iodide & Art & 103 & 111 & 130 & 135 & 143 \\
\hline 10 & Iodide & Induction & 94.1 & 109 & 121 & 128 & 138 \\
\hline 10 & Ames & Arc & 122 & 142 & 151 & 153 & 177 \\
\hline 10 & Ames & Induction & 123 & 132 & 153 & 159 & 175 \\
\hline 5 & Iodide & Arc & 107 & 114 & 123 & 193 & 134 \\
\hline 15 & Iodide & Arc & 98 & 117 & 138 & 138 & 157 \\
\hline 20 & Iodide & Arc & 105 & 132 & 141 & 150 & 157 \\
\hline
\end{tabular}

Examination of the data for the arc-melted iodide alloys indicates little effect of uranium on the as-hot-rolled hardness. However, as uranium content increased, the rate of work hardening increased.

Recrystallization of cold-worked thorium-uranium alloys was found to be extremely sensitive to the amount of cold work imparted and to the temperature of heat treatment. Hardness changes accompanying recrystallization heat treatments are shown in Figures 5 through 8.

The effect of annealing thorium-10 w/o uranium-alloy specimens at 675,700 , and $725 \mathrm{C}$ after 80 per cent cold reduction is shown in Figure 5. The hardness decreased. sharply and then leveled off; the time at which the leveling off occurred increased from about 3 to 7 min with decreasing temperature. While this decrease in hardness might normally be attributed to recrystallization, metallographic observation indicated that the hardness decrease was the result of a combination of recrystallization and grain growth. The same alloy, when annealed at $800 \mathrm{C}$ following a 60 per cent cold reduction also underwent partial recrystallization and grain growth. The duplex grain structure, typical of that resulting from a combination of these two processes is shown in Figure $4 \mathrm{~h}$. A fully recrystallized structure produced by annealing at $800 \mathrm{C}$ following a 90 per cent cold reduction was previously shown in Figure $4 \mathrm{~g}$. 


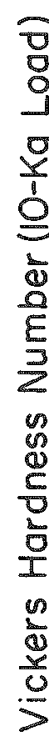

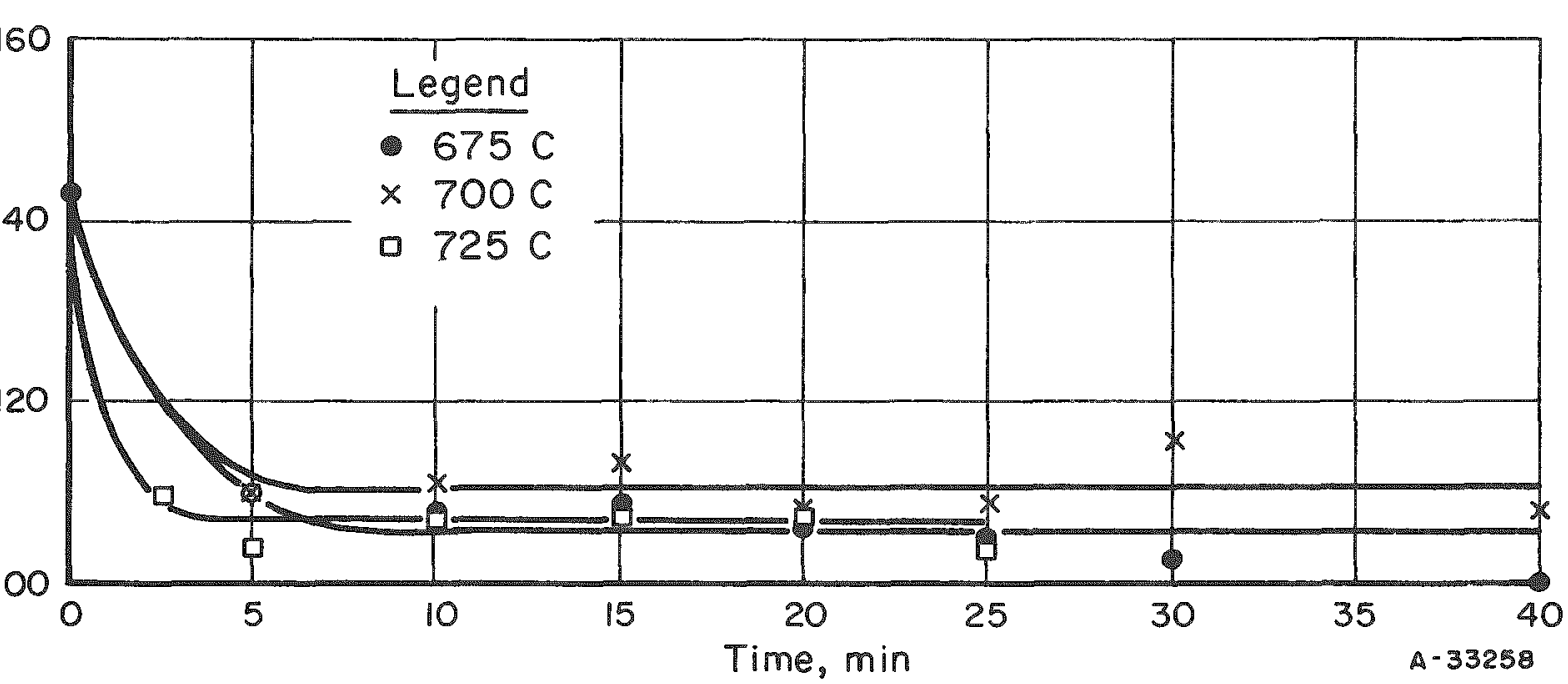

FIGURE 5. DECREASE IN HARDNESS WITH TIME AT TEMPERATURE FOR ARC-CAST 80 PER CENT COLD-REDUCED IODIDE THORIUM$10 \mathrm{w} / \mathrm{O}$ URANIUM

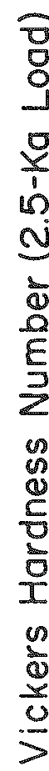

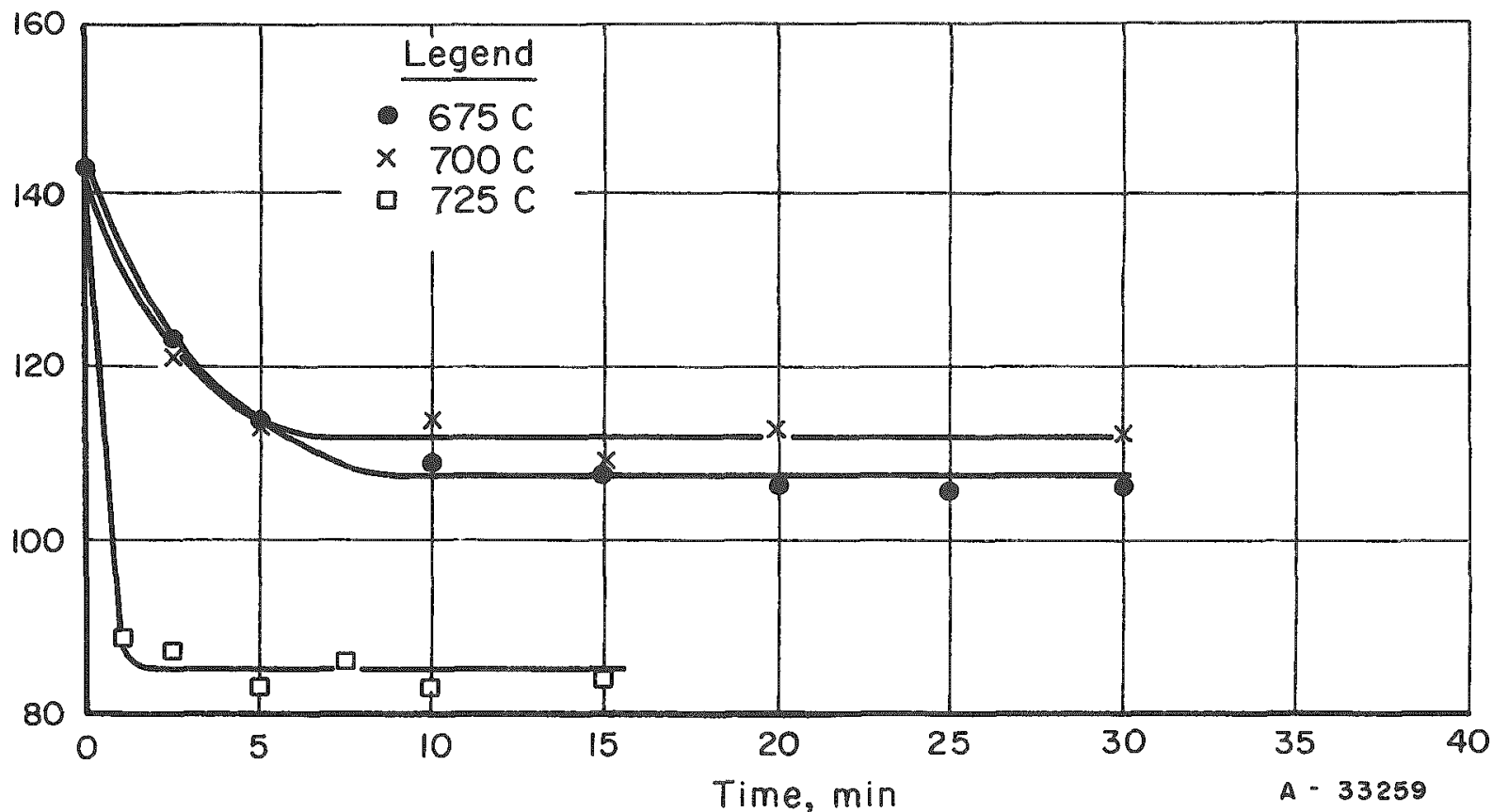

FIGURE 6. DECREASE IN HARDNESS WITH TIME AT TEMPERATURE FOR ARC-CAST 90 PER CENT COLD-REDUCED IODIDE THORIUM $-10 \mathrm{w} / 0$ URANIUM 


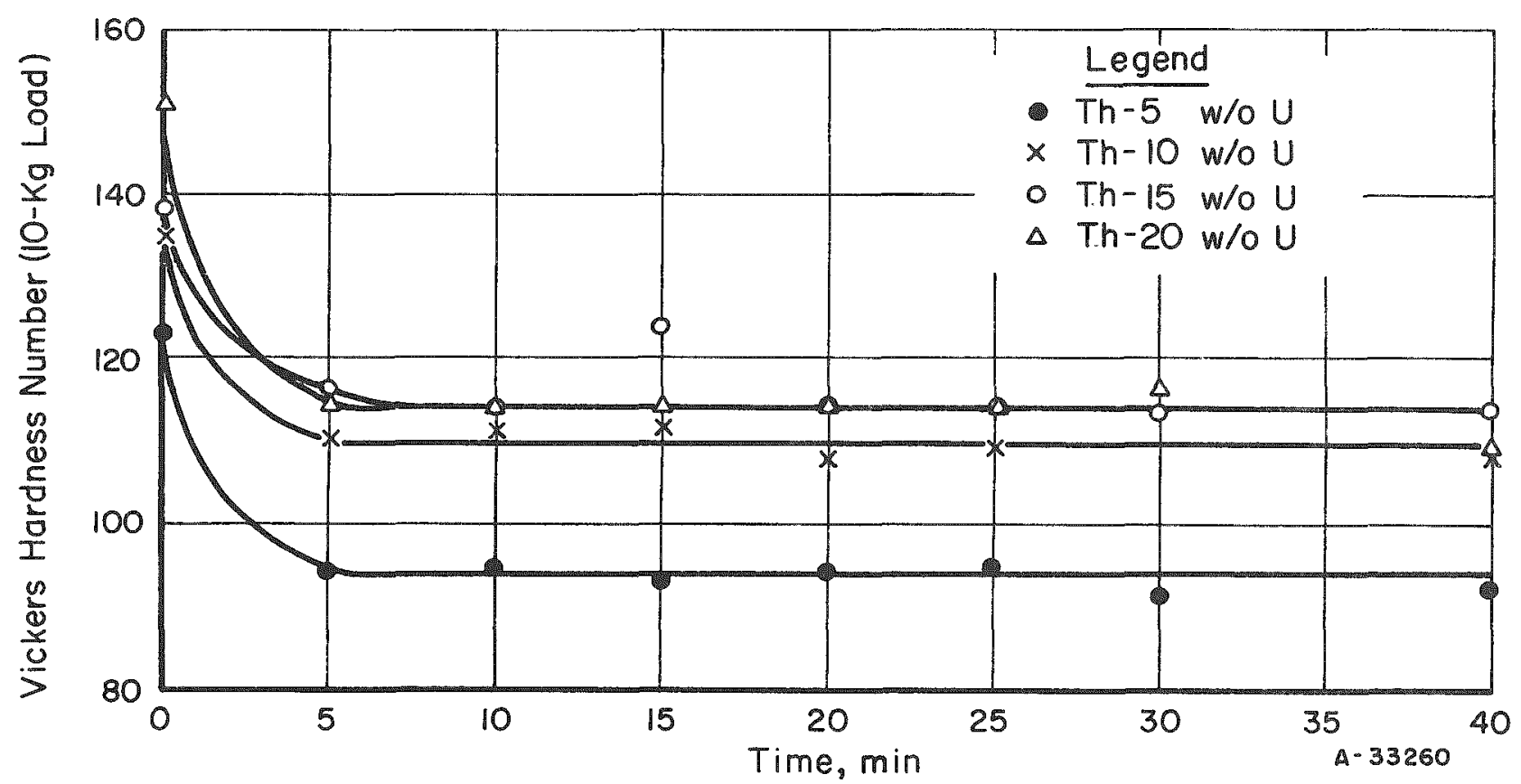

FIGURE 7. DECREASE IN HARDNESS WITH TIME AT $700 \mathrm{C}$ FOR ARCMELTED 80 PER CENT COLD-REDUCED IODIDE THORIUMURANIUM ALLOYS

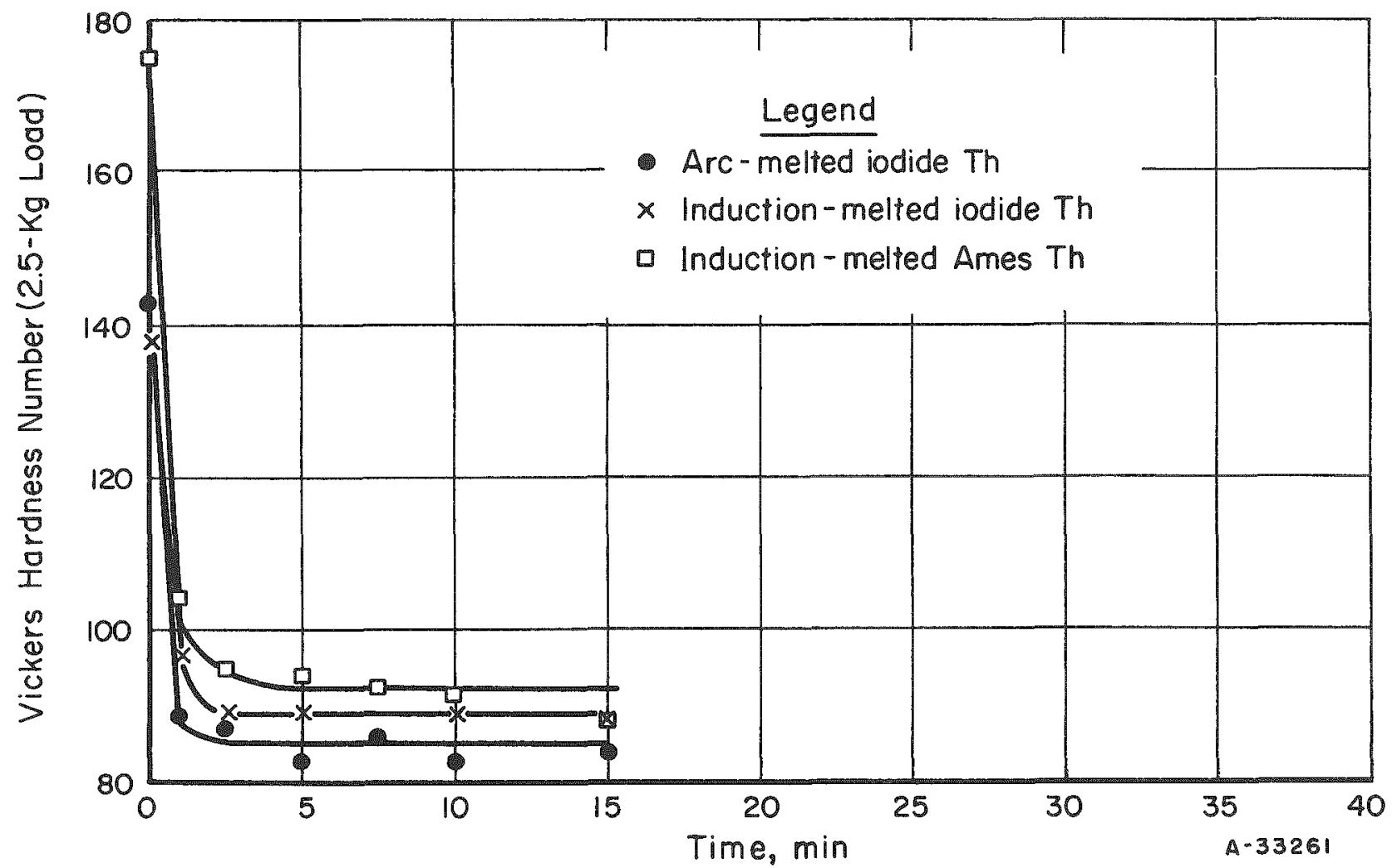

FIGURE 8. DECREASE IN HARDNESS WITH TIME AT 725 C FOR 90 PER CENT COLD-REDUCED THORIUM- $10 \mathrm{w} / 0$ URANIUM ALLOYS 
Specimens cold reduced 90 per cent and annealed at 675 and $700 \mathrm{C}$ showed behavior similar to the 80 per cent reduced material (Figure 6). Only at $725 \mathrm{C}$ did complete recrystallization occur, with recrystallization being accompanied by a much larger and more rapid hardness decrease than accompanies the process of partial recrystallization and grain growth.

On the basis of these observations, it appears that a critical amount of cold work and a critical temperature of heat treatment are required for complete recrystallization of the thorium-uranium alloys. The fact that stress relief in material with low degrees of cold work and at low temperatures occurs by a combination of recrystallization and grain growth indicates a nonuniform stress concentration in the initially cold-worked material. The uranium-phase particles present in the structure are undoubtedly responsible for this lack of uniformity, the stress probably concentrating in the vicinity of the uranium particles.

It should be noted that the recrystallization temperature of thorium is about $600 \mathrm{C}$. Thus the presence of uranium in the structure effectively raises the recrystallization temperature by over $100 \mathrm{C}$.

No effect of composition between 5 and 20 w/o uranium or of purity of the alloy materials on recrystallization behavior was noted. Figure 7 shows the hardness changes that accompanied heat treatment at $700 \mathrm{C}$ of $5,10,15$, and $20 \mathrm{w} / 0 \mathrm{uranium}-$ alloy specimens cold reduced 80 per cent. While the initial and final hardnesses were dependent on composition, none of the specimens underwent complete recrystallization. Figure 8 shows the hardness changes that accompanied recrystallization of thorium-10 w/o uranium alloy specimens prepared from different grades of thorium and by different melting techniques. Again the principal difference in behavior of the materials was in the initial and final hardnesses, the final hardness decreasing slightly with increasing purity of the final alloy material.

Hot Hardness

The results of hot-hardness tests on cast binary thorium-uranium-alloy samples are given in Table 2. Carbon is one of the most potent strengtheners of thorium. For this reason the Ames thorium, which contained approximately five times as much carbon as the iodide thorium, was hardex than the iodide material. This effect carried over to the alloys, with the result that the Ames thorium alloys were harder than the alloys prepared from iodide thorium. However, the strengthening effect of carbon is lost at temperatures above $600 \mathrm{C}$. Apparently the lattice strain at low temperatures due to the interstitial carbon atoms is relieved by the lattice expansion of thorium as it is heated.

Increased uranium content did not produce any pronounced hardening effect. In fact, at the higher temperatures, 800 and $900 \mathrm{C}$, some decrease in hardness appeared to occur as uranium content increased. Uranium itself is much softer than thorium at these temperatures, with the result that the bulk hardness is lower due to the greater volume of uranium present. No evidence of dispersion hardening was noted, probably because dislocation motion is relatively unimpeded by the spheroidal uranium particles. 
TABLE 2. HOT-HARDNESS DATA FOR THORIUM-URANIUMI ALLOYS

\begin{tabular}{|c|c|c|c|c|c|c|c|c|c|}
\hline \multirow{2}{*}{$\begin{array}{c}\text { Usanium Content } \\
\text { (Balance Thorium), } \\
\text { w/o }\end{array}$} & \multirow{2}{*}{$\begin{array}{c}\text { Type of } \\
\text { Thollum Used }\end{array}$} & \multirow{2}{*}{$\begin{array}{l}\text { Meltung } \\
\text { Method }\end{array}$} & \multicolumn{7}{|c|}{ DPH at Temperature Indicated } \\
\hline & & & Room & $200 \mathrm{C}$ & $400 \mathrm{C}$ & $500 \mathrm{C}$ & $600 \mathrm{C}$ & $800 \mathrm{C}$ & $900 \mathrm{C}$ \\
\hline \multirow[t]{3}{*}{5} & Anes & Arc & 139 & 162 & 81.6 & 62.8 & 45.4 & 24.0 & 14.1 \\
\hline & Iodıde & Arc & 100 & 76.5 & 58.6 & 51.2 & 41 & - & -- \\
\hline & Ames & Induction & 134 & 100 & 73.9 & 65.4 & 45.1 & 9.0 & - \\
\hline \multirow[t]{4}{*}{10} & Ames & Arc & 137 & 96.6 & 76.4 & 65.5 & 45.4 & 22.1 & 11.2 \\
\hline & Iodide & Arc & 111 & -- & 71.5 & 59.5 & 44.0 & 17.1 & 16.6 \\
\hline & Ames & Induction & 141 & 102 & 76.2 & 62.2 & 47.3 & 24.6 & - \\
\hline & Iodide & Induction & 104 & 80.5 & 66.3 & 55.4 & 38.8 & 18.8 & 11.8 \\
\hline \multirow[t]{2}{*}{15} & Ames & Arc & 145 & -- & 82.3 & 65.8 & 39.2 & 10.6 & 4.2 \\
\hline & Iodzde & Arc & 115 & 90.1 & 67.9 & 56.2 & 34.4 & 13.6 & - \\
\hline \multirow[t]{4}{*}{20} & Ames & Arc & 148 & 120 & 90.0 & 68.6 & 46.2 & 14.0 & $=$ \\
\hline & Iodide & Arc & 119 & 92.2 & 73.2 & 57.0 & 43.3 & - & 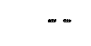 \\
\hline & Ames & Induction & 148 & 101 & 78.5 & 66.0 & 41.8 & 15.3 & 10.2 \\
\hline & Iodude & Induction & 118 & 102 & 82.5 & 59.3 & 37.5 & 12.5 & 9.2 \\
\hline
\end{tabular}

\section{Density Determinations}

The densities of thorium and thorium-base uranium alloys are reported in Table 3. The value obtained for the density of iodide thorium was $11.71 \mathrm{~g}$ per $\mathrm{cm}^{3}$, which is

TABLE 3. DENSITIES OF ARC-MELTED AND COLD -REDUCED THORIUM AND THORIUM-URANIUM ALLOYS

\begin{tabular}{lc}
\hline Alloy Composition, w/o & Density, g per cm \\
\hline Ames Th & 11.60 \\
Ames Th-5 w/o U & 11.79 \\
Ames Th-10 w/o U & 12.01 \\
Ames Th-15 w/o U & 12.30 \\
Ames Th-20 w/o U & 12.59 \\
Iodide Th & 11.71 \\
Iodide Th-5 w/o U & 11.88 \\
Iodide Th-10 w/o U & 12.10 \\
Iodide Th-15 w/o U & 12.33 \\
Iodide Th-20 w/o U & 12.58 \\
\hline
\end{tabular}


close to the theoretical density of $11.72 \mathrm{~g}$ per $\mathrm{cm}^{3}$, based on a lattice parameter of $5.086 \mathrm{~A}$. The Ames thorium was considerably less dense, $11.60 \mathrm{~g} \mathrm{per} \mathrm{cm}^{3}$. The presence of $\mathrm{ThO}_{2}$ inclusions accounts for the low density of the Ames material. Likewise, the thorium-uranium alloys containing Ames thorium were less dense than the corresponding iodide alloys. A plot of these densities versus atomic per cent composition was linear, with minor variances being due to deviations in nominal composition and oxygen content of the specimens measured.

Ternary and Quaternary Thorium-Uranium Alloys

\section{Microstructure}

The thorium-10 w/o uranium-1.5 w/o molybdenum alloy exhibited a cast structure nearly identical to the arc-cast thorium-10 w/o uranium alloys; that is, a structure containing a fairly uniform dispersion of the uranium-rich phase. The structure of the thorium-10 w/o uranium-2 w/o niobium alloy was not quite so similar and is illustrated in Figure 9a. As can be seen, the uranium particle distribution is uniform; however, the shape of the particles indicates that they reside in and conform closely to the shape of grain boundaries. The thorium-20 w/o uranium-3 w/o molybdenum and $-4 \mathrm{w} / \mathrm{o}$ niobium alloys, because of their high alloy content, exhibited high concentrations of uranium-rich phase in the grain boundaries. These alloys, with additions of molybdenum and niobium, were very similar to the corresponding binary alloys of the same uranium concentration.

Additions of zirconium to thorium-uranium alloys cause a significant change in microstructure, as the zirconium goes into solution in both the uranium and the thorium. The thorium-10 w/o uranium-10 w/o zirconium alloy exhibited a cast structure of uranium-rich-phase particles dispersed throughout the thorium gxains and also concentrated in the grain boundaries. The thorium $-20 \mathrm{w} / 0$ uranium-20 w/o zirconium and $25 \mathrm{w} / 0$ uranium-25 w/o zirconium alloys had cast structures that consisted of an intimate mixture of thorium-rich and uranium-rich phases. Thus, at these high alloy contents the microstructures can no longer be described as a simple mixture of uranium particles in a thorium matrix.

Additions of niobium and zirconium together to thorium-uranium result in further modifications of structure. The as-cast structures of thorium-10 w/o uranium$5 \mathrm{w} / 0$ zirconium $-2 \mathrm{w} / 0$ niobium, $-10 \mathrm{w} / 0$ uranium $-10 \mathrm{w} / 0$ zirconium $-2 \mathrm{w} / 0$ niobium, $-15 \mathrm{w} / \mathrm{o}$ uranium $-15 \mathrm{w} / \mathrm{o}$ zirconium- $3 \mathrm{w} / \mathrm{o}$ niobium and $-15 \mathrm{w} / \mathrm{o}$ uranium $-7.5 \mathrm{w} / \mathrm{o}$ w/o zixconium-3 w/o niobium alloys all exhibited very large amounts of a uraniumrich phase, appearing as large particles within the thorium-rich phase. An example of the structures obtained in this group of alloys is shown in Figure 9b. This figure depicts the thorium-15 w/o uranium-15 w/o zirconium-3 w/o niobium alloy in the as-cast condition. When the uranium content was increased, the matrix structure underwent a maxked change. The tho rium-20 w/o uranium-10 w/o zirconium-4 w/o niobium and $-20 \mathrm{w} / 0$ uranium-20 w/o zirconium-4 w/o niobium had as-cast structures showing large uranium-rich dendritic particles in a matrix consisting of an intimate two-phase mixture. This is illustrated in Figure 9c, which shows the as-cast structure of thorium$20 \mathrm{w} / 0$ uranium-20 w/o zirconium $-4 \mathrm{w} / 0$ niobium. 


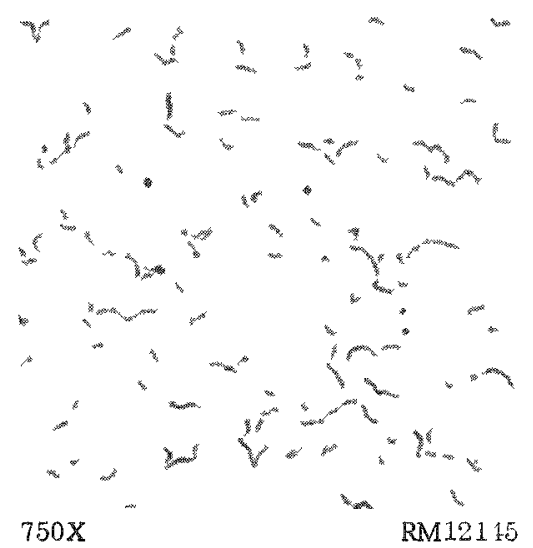

a 10 w/o Uranıum-2 w/o Niobıum As Cast

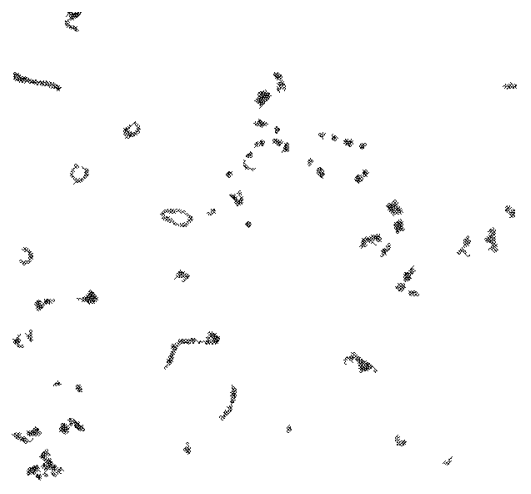

$750 \mathrm{X}$

RM12083

d. $10 \mathrm{w} / \mathrm{o}$ Uranum $-1.5 \mathrm{w} / \mathrm{o}$ Molybdenum Hot Rolled, Cold Reduced 50 Per Cent, Heated $24 \mathrm{Hr}$ at $800 \mathrm{C}$, and Water Quenched

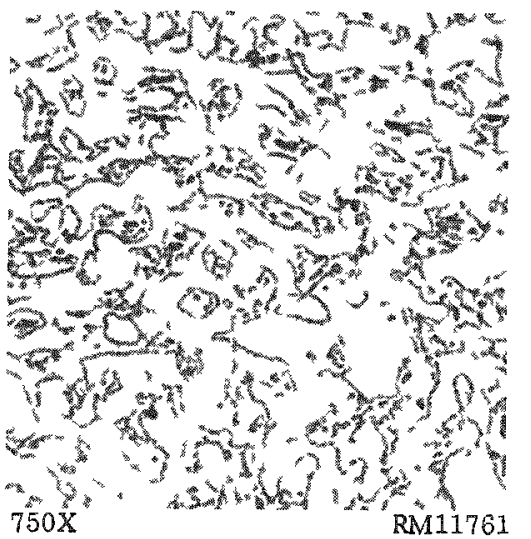

$25 \mathrm{w} / 0$ Uranum $-25 \mathrm{w} / 0 \mathrm{Zurconum}$ Heated $24 \mathrm{Hr}$ at $1000 \mathrm{C}$ and Furnace Cooled

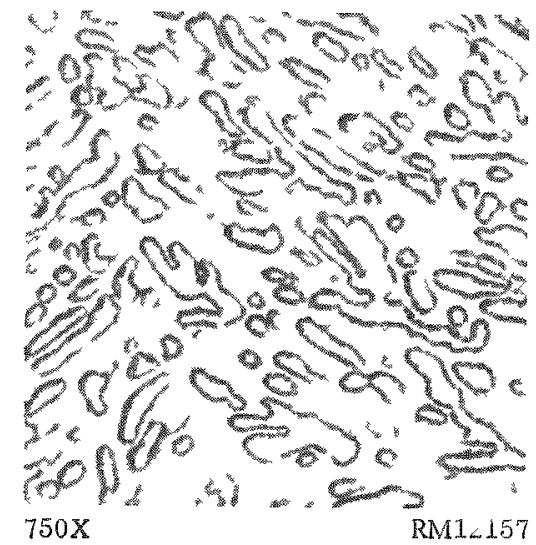

b. $15 \mathrm{w} / \mathrm{o}$ Uranum $-15 \mathrm{w} / 0$ Zirconium3 w/o Niobium As Cast

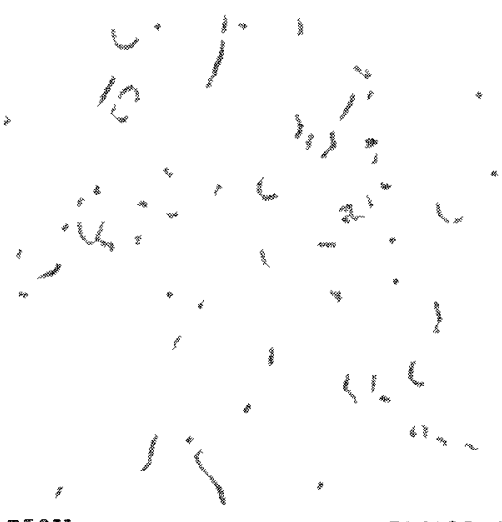

$750 \mathrm{X}$

RM12381

e. $10 \mathrm{w} / \mathrm{o}$ Uranum-2 w/o Niobıum Hot and Cold Reduced 50 Per Cent, Heated $24 \mathrm{Hr}$ at $1000 \mathrm{C}$. and Furnace Cooled

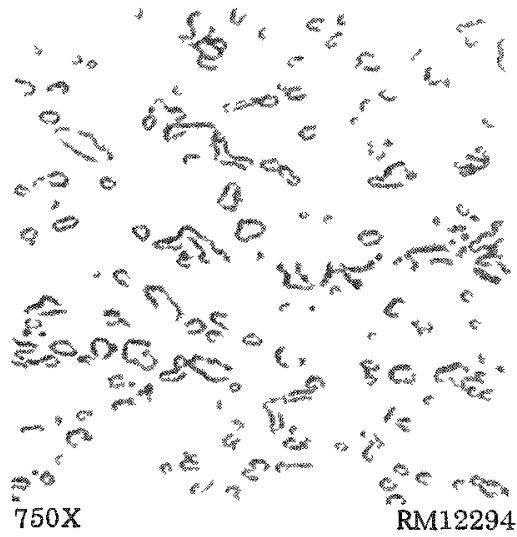

$10 \mathrm{w} / \mathrm{o}$ Uranıum $-5 \mathrm{w} / \mathrm{o}$ Zirconum2 w/o Niobium Heated $24 \mathrm{Hr}$ at $800 \mathrm{C}$ and Water Quenched

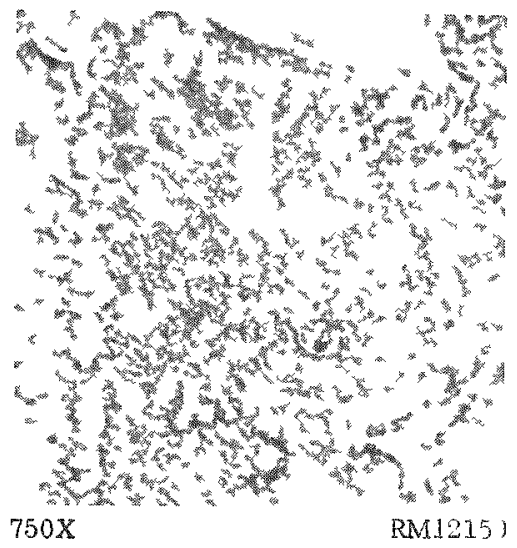

c. $20 \mathrm{w} / \mathrm{o}$ Uranum-20 W/o Zirconıum4 W/o Nlobium As Cast

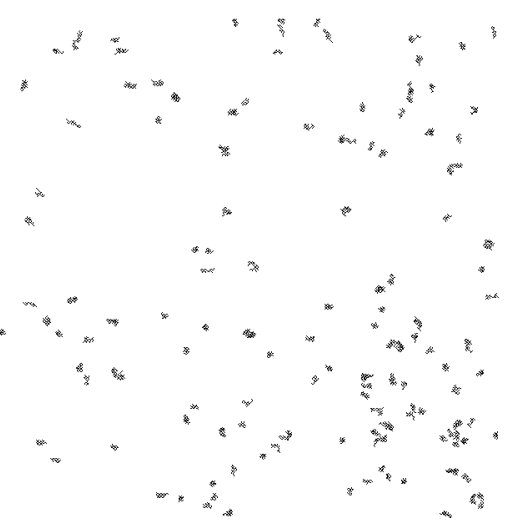

RM11759

f. $25 \mathrm{w} / \mathrm{o}$ Uranum-25 w/o Zirconum Heated $24 \mathrm{Hr}$ at $1000 \mathrm{C}$ and Water Quenched

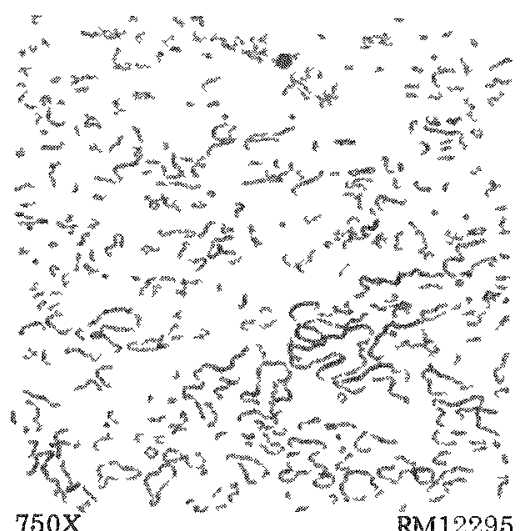

RM12295

1. $20 \mathrm{w} / 0$ Uranium-10 w/o Zirconium$4 \mathrm{w} / \mathrm{O}$ Niobıum Heated $24 \mathrm{Hr}$ at $800 \mathrm{C}$ and Water Quenched

FIGURE 9. MICROSTRUCTURES OF THORIUM-URANIUM TERNARY AND QUA TERNARY ALLOYS 
In general, small reductions by hot rolling and cold working had a minox effect on the microstructure of the ternary and quaternary alloys. A longitudinal section of a thorium-10 w/o uranium $-1.5 \mathrm{w} / 0$ molybdenum alloy is shown in Figure $9 \mathrm{~d}$. This alloy was hot worked and then cold reduced for a total of 50 per cent reduction in area. Note that there is no definite preferred orientation of uranium particles.

Annealing treatments at 1000 and $800 \mathrm{C}$, followed by both furnace cooling and water quenching, were performed on the ternary and quaternary alloys. The thoriumuranium-niobium and-molybdenum alloys heat treated at $1000 \mathrm{C}$ and furnace cooled showed agglomeration of the uranium particles. This can be seen for the case of the niobium-containing alloy by comparing Figures $9 a$ and $9 e$. Figure $9 a$ depicts this alloy in the as-cast state, while Figure $9 \mathrm{e}$ shows this alloy after heating at $1000 \mathrm{C}$ for $24 \mathrm{hr}$ and furnace cooling. The agglomeration and spheroidization of uranium particles as a result of heat treatment is very striking. Of note are the very small particles of uranium that are located between the larger ones. These small particles evidently precipitated from solution during furnace cooling.

The thorium-uranium-zirconium alloys heat treated at 800 and $1000 \mathrm{C}$ and water quenched exhibited two-phase structures of a uranium-rich constituent in a matrix of alpha thorium. The thorium $-25 \mathrm{w} / 0$ uranium-25 w/o zirconium alloy quenched from $1000 \mathrm{C}$ (Figure 9f) showed what appeared to be a fine-grained single-phase structure. $\mathrm{X}$-ray diffraction study (Table 4) indicated that this alloy and a thorium-20 w/o uranium$20 \mathrm{w} / 0$ zirconium alloy quenched from $1000 \mathrm{C}$ contained a mixture of a body-centeredcubic phase and face-centered-cubic phase and face-centered-cubic alpha thorium. The body-centered-cubic phase, a solid solution of gamma uranium, beta zirconium, and beta thorium, can be considered as a gamma-uranium solid solution.

These same alloys, when furnace cooled from $1000 \mathrm{C}$, contained alpha thorium, but the gamma-uranium phase transformed on slow cooling to delta uranium-zirconium. The furnace-cooled structure of the thorium-25 w/o uranium $-25 \mathrm{w} / 0$ zirconium alloy appears in Figure $9 \mathrm{~g}$. The almost continuous grain-boundary constituent, containing dark speckles, is the delta uranium-zirconium phase. Its existence in this alloy has been supported by X-ray diffraction identification (Table 4).

The thorium-uranium-zirconium-niobium alloys after heat treatment at 1000 and $800 \mathrm{C}$ also exhibited discrete two-phase structures, the amount of uranium-rich phase increasing with the alloy content. The uranium-rich particles in these alloys were randomly distributed, although at high alloy contents they tended to become interconnecting. Figure $9 \mathrm{~h}$ shows the microstructure of thorium-10 w/o uranium-5 w/o zirconium-2 w/o niobium, water quenched after 24 hr at $800 \mathrm{C}$. The particles of uranium-zirconium-niobium were relatively small and fairly randomly distributed. The thorium-20 w/o uranium-10 w/o zirconium-4 w/o niobium alloy is shown in Figure 9i. In this alloy, the particle size was large and the particles were nearly interconnecting, although their distribution was random.

The behavior of these quaternary alloys was unusual in that the general tendency in all of the other binary and ternary alloys was for the uranium-rich phase to precipitate as a continuous grain-boundary phase at high-uranium concentrations and thus assume the role of the matrix phase. In these quaternary alloys, even though the uranium-rich phase particles began to join as they met one another, the thorium still assumed the character of the matrix phase. 
TABLE 4. RESULTS OF X-RAY DIFFRACTION EXAMINATION

\begin{tabular}{|c|c|c|c|c|c|c|c|}
\hline \multirow{2}{*}{$\begin{array}{c}\text { Alloy Composition } \\
\text { (Balance Thorium), } \\
\text { w/o }\end{array}$} & \multirow[b]{2}{*}{ Heat Treatment } & \multicolumn{6}{|c|}{ Intensities $(a)$ and Lattice Parameters $(b)$ of Phase Patterns Observed } \\
\hline & & $\alpha \mathrm{Th}$ & $y \mathrm{U}-\mathrm{Zr}$ & $\gamma \mathrm{U}-\mathrm{Nb}$ & $y \mathrm{U}-\mathrm{MO}$ & $\mathrm{UZr}_{2}$ & $\mathrm{U}_{2} \mathrm{MOaU}$ \\
\hline $20 \mathrm{U}-20 \mathrm{Zr}$ & $1000 \mathrm{C}, \mathrm{W} . \mathrm{Q}$. & VS, 5.036 & $M, 3.606$ & -- & $m-$ & - & -- \\
\hline $20 \mathrm{U}-20 \mathrm{Zr}$ & $1000 \mathrm{C}, \mathrm{F} . \mathrm{C}$. & MS & -- & -- & $-\infty$ & s & $-\infty$ \\
\hline $25 \mathrm{U}-25 \mathrm{Zr}$ & $1000 \mathrm{C}, \mathrm{W} . \mathrm{Q}$ & S, 5.036 & VS, 3.610 & - & $\ldots$ & $-\infty$ & $\cdots$ \\
\hline $25 \mathrm{U}-25 \mathrm{Zr}$ & $1000 \mathrm{C}, \mathrm{F} . \mathrm{C}$. & $\mathbf{M}$ & - & - & $\infty$ & VS & $-\infty$ \\
\hline $10 \mathrm{U}-1.5 \mathrm{Mo}$ & $800 \mathrm{C}, \mathrm{W} . \mathrm{Q}$. & VS, 5.075 & -- & $-\infty$ & $M, 3.39$ & $-\infty$ & -- \\
\hline $10 \mathrm{U}-1.5 \mathrm{Mo}$ & $\begin{array}{l}800 \mathrm{C}, \mathrm{W} . \mathrm{Q} .+200 \mathrm{hr} \\
\text { at } 500 \mathrm{C}, \mathrm{W} . \mathrm{Q} \text {. }\end{array}$ & VS, 5.085 & - & $\cdots$ & VF ? & ext & $M F-V V t$ \\
\hline $20 \mathrm{U}-3 \mathrm{MO}$ & $800 \mathrm{C}, \mathrm{W} . \mathrm{Q}$. & VS, 5.075 & $\rightarrow$ & - & $\mathrm{MF}, 3.39$ & $-\infty$ & $-\infty$ \\
\hline $20 \mathrm{U}-3 \mathrm{MO}$ & $\begin{array}{l}800 \mathrm{C}, W . Q \cdot+200 \mathrm{hr} \\
\text { at } 500 \mathrm{C}, \mathrm{W} . \mathrm{Q} .\end{array}$ & VS, 5.085 & - & - & $F ?$ & $=$ & M-VVE \\
\hline $10 \mathrm{U}-2 \mathrm{Nb}$ & $800 \mathrm{C}, \mathrm{W} . \mathrm{Q}$. & VS, 5.085 & -- & $S, 3.451$ & $-\infty$ & - & $=\infty$ \\
\hline $20 \mathrm{U}-4 \mathrm{Nb}$ & $800 \mathrm{C}$, W.Q. & VS, 5.085 & - & $\mathrm{MS}, 3.432$ & $m$ & $m$ & $-\infty$ \\
\hline $20 \mathrm{U} \sim 4 \mathrm{Nb}$ & $\begin{array}{l}800 \mathrm{C}, W . Q \cdot+70 \text { days } \\
\text { at } 550 \mathrm{C}, W . Q .\end{array}$ & VS, 5.084 & $-\infty$ & $\mathrm{MF}, 3.33$ & $-\infty$ & -- & $\mathrm{F}$ \\
\hline
\end{tabular}

(a) Legend: $S=$ strong

$$
\begin{aligned}
& M I=\text { medium } \\
& F=\text { faint } \\
& V=\text { very } .
\end{aligned}
$$

(b) Lattice parameters are given in angstroms. 


\section{Phase Studies}

The stability of the gamma-uranium particles produced in thorium-uranium alloys containing molybdenum and niobium additions was briefly examined. Metallographic studies of gamma-quenched and aged alloys failed to show detectable transformation within the uranium particles. $\mathrm{X}$-ray diffraction examination was required to show the transformation of the gamma-phase particles during low-temperature aging. Data are recorded in Table 4.

After aging for long periods of time, faint patterns of alpha uranium were detected in both the molybdenum- and niobium-containing alloys. In the molybdenum alloy, alpha precipitation was accompanied by the formation of $\mathrm{U}_{2} \mathrm{Mo}$; residual gamma might have been present but its identification was uncertain. Alpha precipitation in the niobium alloys was accompanied by a marked shift in the gamma lattice parameter indicative of niobium enrichment of the gamma phase.

Slight shifts also occurred in the alpha-thorium lattice parameter. The increase in lattice spacing was indicative of rejection of the smaller uranium and possibly niobium or molybdenum atoms from solid solution.

Thermal-analysis data for thorium-uranium-zirconium and thorium-uraniumzirconium-niobium alloys are reported in Table 5. The tentative phase transformations as sociated with the thermal effects recorded are deduced from consideration of the phase relations in the binary systems involved and from phase relations reported by Russian investigators $(2)$.

\section{Hot Hardness}

The effect of ternary and quaternary alloying on the hot hardness of thoriumuranium alloys is shown in Table 6.

At temperatures of $600 \mathrm{C}$ and below, zirconium was found to be the most effective hardener of the thorium-uranium alloys. This strengthening effect is believed to arise primarily from dispersion hardening of the thorium matrix, although hardening due to solid solution of zirconium in thorium may contribute. However, at higher temperatures, this effect was lost, the zirconium-containing alloys exhibiting an abrupt softening at about $600 \mathrm{C}$. The quaternary alloys containing zirconium and niobium also showed this effect.

The molybdenum- and niobium-containing alloys, on the other hand, were softer than the corresponding binary alloys at temperatures of $600 \mathrm{C}$ and below. While these alloys also exhibited softening in the vicinity of $600 \mathrm{C}$, the degree of softening above this temperature was not so drastic as for the zirconium-containing alloys.

Above $600 \mathrm{C}$, ternary and quaternary additions to thorium-uranium-base alloys had a significant effect on hardness. Furthermore, the effectiveness of the alloy additions in producing hardening over that of binary alloys increased with increasing uranium content. Ternary additions of molybdenum, niobium, and zirconium appeared to be most effective at the $10 \mathrm{w} / \mathrm{o}$ uranium level, while the quaternary additions appeared 
TABLE 5. PHASE TRANSFORMAIIONS AS DETECTED BY THERMAL ANALYSIS IN T HORIUM-URANUUM-ZIRCONIUR AND THORIUM-URANIUM-ZIR CONIUM-NTOBIUM ALLOYS

\begin{tabular}{|c|c|c|c|c|c|c|c|c|c|}
\hline \multirow[b]{2}{*}{ Tentat2ve Phase Iransformation } & \multicolumn{9}{|c|}{ Iransformation iemperature, $c$} \\
\hline & $\begin{array}{l}\mathrm{Th}-10 \mathrm{w} / 0 \mathrm{U} \\
-10 \mathrm{w} / 0 \mathrm{Zr}\end{array}$ & $\begin{array}{l}\mathrm{Th}-20 \mathrm{w} / 0 \mathrm{U} \\
-20 \mathrm{w} / 0 \mathrm{zr}\end{array}$ & $\begin{array}{l}\text { Ih-25 w/oU } \\
-25 \mathrm{w} / 0 \mathrm{Zr}\end{array}$ & $\begin{array}{l}\text { Th- } 10 \mathrm{w} / \mathrm{ov} \\
-5 \mathrm{w} / \mathrm{Zr} \\
-2 \mathrm{w} / \mathrm{No}\end{array}$ & $\begin{array}{l}\text { Ih-20 w/oU } \\
-10 w / 0 \mathrm{Zr} \\
-4 \mathrm{w} / \mathrm{ONb}\end{array}$ & $\begin{array}{l}\text { Th-10 w/oU } \\
-10 \mathrm{w} / 0 \mathrm{zr} \\
-2 \mathrm{w} / 0 \mathrm{Rb}\end{array}$ & $\begin{array}{l}T h-15 \mathrm{w} / 0 \mathrm{U} \\
-15 \mathrm{w} / 0 \mathrm{Zr} \\
-3 \mathrm{w} / 0 \mathrm{Nb}\end{array}$ & $\begin{array}{l}\mathrm{Th}_{-15} \mathrm{w} / \mathrm{oU} \\
-7.5 \mathrm{w} / \mathrm{Or} \\
-3 \mathrm{w} / \mathrm{No}\end{array}$ & $\begin{array}{l}\mathrm{Th}-20 \mathrm{w} / 0 \mathrm{U} \\
-20 \mathrm{w} / \mathrm{OZ} \\
-4 \mathrm{w} / \mathrm{O} \mathrm{Nb}\end{array}$ \\
\hline $\mathrm{Th}+\mathrm{UZ}_{2}+a \mathrm{Th}+\mathrm{U} z_{\mathrm{r}} \overline{2}+\overline{\mathrm{U}-2 \mathrm{r}}$ & 550 & 552 & 549 & -- & -- & $-\infty$ & 529 & -- & -- \\
\hline$y h_{1}=\mathrm{U} Z_{2}+\gamma \mathrm{U}-Z_{\mathrm{x}}+u_{\mathrm{T}} \mathrm{Th}+\gamma \mathrm{U}-Z_{\mathrm{r}}$ & 583 & 585 & 587 & $\cdots$ & - & - & 504 & $-\infty$ & - \\
\hline$x T h+\gamma U-Z x \rightarrow T h+\gamma U-Z r+31 \mathrm{~h}$ & 963 & 906 & 990 & 1083 & 1072 & 1017 & 1017 & 1008 & 1016 \\
\hline$\alpha T h+\gamma U-Z r+\beta T h \rightarrow o T h+\gamma U-Z r$ & 1045 & 999 & 1002 & 1145 & 1102 & 1064 & 1030 & 1088 & 1030 \\
\hline$\beta T h_{1}+\gamma U-Z r \rightarrow \beta T h+$ liquad & 1165 & 1200 & 1199 & 1224 & 1185 & 1187 & 1178 & 1201 & 1179 \\
\hline$r x_{2}+1_{1} q_{1} u_{1} d \rightarrow 1_{1} q u d d$ & 1183 & 1262 & 1239 & 1263 & 1227 & 1212 & 1194 & 1237 & 1195 \\
\hline
\end{tabular}

TABLE 6. HOT HARDNESS OF AS-CAST THORIUM-URANIUM-BASE ALLOYS PREPARED FROM IODIDE THORILM

\begin{tabular}{|c|c|c|c|c|c|c|c|}
\hline \multirow{2}{*}{$\begin{array}{c}\text { Composition } \\
\text { (Balance Thorium), w/o }\end{array}$} & \multicolumn{7}{|c|}{ Diannond Pyramid Hardness, $\mathrm{kg}$ per $\mathrm{mm}^{2}$} \\
\hline & $25 \mathrm{C}$ & $200 \mathrm{C}$ & $400 \mathrm{C}$ & $500 \mathrm{C}$ & $600 \mathrm{C}$ & $800 \mathrm{C}$ & $901: C$ \\
\hline$-10 \mathrm{U}$ & 111 & $=$ & 71.5 & 59.5 & 44.0 & 17.1 & 10.6 \\
\hline$-10 C^{\top}-1.5 \mathrm{NO}$ & 72.9 & 59.4 & 54.4 & 48.4 & 41.1 & 22.4 & -- \\
\hline$-10 \mathrm{U}-2 \mathrm{Nb}$ & 89.4 & 71.3 & 60.7 & 57.2 & 42.7 & 20.3 & $\cdots$ \\
\hline$-10 \mathrm{U}-10 \mathrm{Zr}$ & 161 & 152 & 128 & 1.16 & 54.5 & 22.2 & $\ldots$ \\
\hline$-10 \mathrm{C}-5 \mathrm{Zr}-2 \mathrm{Nb}$ & 110 & 87.4 & 84.2 & 78.7 & 57.8 & $18_{0}$ & $11 \% .7$ \\
\hline$-10 \mathrm{~T}-10 \mathrm{Zr}-2 \times \mathrm{Db}$ & 138 & 119 & 110 & 96.4 & 73.2 & 17.2 & 8.5 \\
\hline$-15 \mathrm{U}$ & 115 & 90.1 & 67.9 & 56.2 & 34.4 & 13.6 & $\cdots$ \\
\hline$-.15 \mathrm{U}-7.5 \mathrm{Zr} .3 \mathrm{Nb}$ & 146 & 111 & 106 & 95.9 & 65.0 & 24.9 & 13.1 \\
\hline$-15 \mathrm{UJ}-15 \mathrm{Zr}-3 \mathrm{Nb}$ & 173 & 141 & 137 & 113 & 81.5 & 20.4 & 10.4 \\
\hline$-20 \mathrm{U}(\mathrm{a})$ & 118 & 102 & 82.5 & 59.3 & 37.5 & 12.5 & 9.2 \\
\hline$-20 \mathrm{U}-3 \mathrm{MO}$ & 103 & 75.8 & 62.7 & 61.8 & 54.3 & 21.5 & - \\
\hline$-20 U-4 N b$ & 94.8 & 77.7 & 66.6 & 64.2 & 52.5 & - & $-\infty$ \\
\hline$-20 U-20 \mathrm{ZI}$ & 226 & 210 & 190 & 161 & 65.5 & 17.6 & $m$ \\
\hline$-20 \mathrm{U}-10 \mathrm{Zr}-4 \mathrm{Nb}$ & 153 & 125 & 116 & 106 & 80.1 & 23.6 & 13.8 \\
\hline$-25 \mathrm{U}-25 \mathrm{Zr}$ & 252 & 235 & 194 & -- & 62.7 & 22.5 & 12.8 \\
\hline
\end{tabular}

(a) Induction-melted alloy. All other alloys were arc melted. 
to increase in effectiveness at the higher uranium levels. Based on the quaternaryalloy data at the 10 and 15 w/o uranium levels where zirconium content of the quaternary alloy was varied, it appears that with niobium present, a lower zirconium content pro-duces greater hardening than a higher zirconium content.

\section{Corrosion Results}

Corrosion tests were conducted in degassed and deionized $200 \mathrm{C}$ water. Results are reported in Table 7. In addition to thorium-uranium-zirconium and thoriumuranium-zirconium-niobium alloys, alloys containing ruthenium, titanium, yttrium, and rare-earth additions were tested.

The reported value for the corrosion rate of thorium is $-1.5 \mathrm{mg} /\left(\mathrm{cm}^{2}\right)(\mathrm{hr})$ in $200 \mathrm{C}$ water. (3) Improvement afforded by alloying as found in this investigation is, at best, twofold.

The most resistant alloys were, in general, those that contained high zirconium concentrations. Of the group of specimens water quenched from $1000 \mathrm{C}$, thr thorium$10 \mathrm{w} / 0$ uranium-10 $\mathrm{w} / 0$ zirconium-2 $\mathrm{w} / 0$ niobium and thorium $-20 \mathrm{w} / 0$ uranium-20 $/ 0$ zirconium alloys exhibited corrosion rates of about one-half that reported for thorium. The thorium- $25 \mathrm{w} / 0$ uranium $-25 \mathrm{w} / 0$ zirconium alloy corroded at an average rate of -0.24 and $-0.55 \mathrm{mg} /\left(\mathrm{cm}^{2}\right)(\mathrm{hr})$ after testing for 168 and $336 \mathrm{hr}$, respectively. However, after $504 \mathrm{hr}$ the rate increased to $-1.17 \mathrm{mg} /\left(\mathrm{cm}^{2}\right)(\mathrm{hr})$. The same alloy, furnace cooled from $1000 \mathrm{C}$, exhibited a corrosion rate after $504 \mathrm{hr}$ of only $-0.79 \mathrm{mg} /\left(\mathrm{cm}^{2}\right)(\mathrm{hr})$. The marked rate increase of the water-quenched thorium-25 w/o uranium- 25 w/o zirconium alloy may have been due to stresses accompanying transformation of the gamma uranium-zirconium phase.

Of the alloys corrosion tested after furnace cooling from $1000 \mathrm{C}$, only the uranium $-25 \mathrm{w} / 0$ uranium-25 w/o zirconium alloy exhibited comparatively low corrosion rates in the 504-hr test period.

Rare-earth, ruthenium, and titanium additions to either thorium-10 w/o uranium or thorium-10 w/o uranium-10 w/o zirconium alloys did not significantly improve corrosion resistance. However, alloys containing these additions, when quenched from $1000 \mathrm{C}$, did exhibit decreasing corrosion rates with increased test times. This indicates that a semiprotective oxide coating may form as corrosion proceeds.

\section{DISCUSSION}

Binary Thorium-Uranium Alloys

Thorium-uranium alloys prepared from Ames and iodide thorium show little difference in microstructure either in the as-cast or worked state, aside from the presence of a greater number of oxide inclusions in the alloys prepared from Ames thorium. This results from the higher oxygen content of this material. The higher 
TABLE 7. CORROSION DATA FOR THORIUM TERNARY AND QUATERNARY ALLOYS EXPOSED IN 200 C WATER

\begin{tabular}{|c|c|c|c|c|c|}
\hline \multirow{2}{*}{$\begin{array}{c}\text { (Balance Thorium, } \\
\text { Alloy Composition } \\
w / o\end{array}$} & \multicolumn{5}{|c|}{ Corrosion Rate, $\left.\mathrm{mg} /\left(\mathrm{cm}^{2}\right) \mathrm{hr}\right)$, at Time Interval Indicated } \\
\hline & $24 \mathrm{Hr}$ & $72 \mathrm{Hr}$ & $168 \mathrm{Hr}$ & $336 \mathrm{Hr}$ & $504 \mathrm{Hr}$ \\
\hline \multicolumn{6}{|c|}{ Heated $24 \mathrm{Hr}$ at $1000 \mathrm{C}$, Water Quenched } \\
\hline $10 \mathrm{U}-10 \mathrm{Zr}$ & -1.51 & -1.49 & -1.25 & -1.41 & -1.21 \\
\hline $20 \mathrm{U}-20 \mathrm{Zr}$ & -0.13 & -0.68 & -0.68 & -0.80 & -0.80 \\
\hline $25 \mathrm{U}-25 \mathrm{Zr}$ & +0.04 & -0.01 & -0.24 & -0.55 & -1.17 \\
\hline $10 \mathrm{U}-5 \mathrm{Zr}-2 \mathrm{Nb}$ & -2.20 & -2.12 & -2.11 & -1.91 & -1.76 \\
\hline $20 \mathrm{U}-10 \mathrm{Zr}-4 \mathrm{Nb}$ & +0.37 & -2.72 & -2.04 & -2.60 & -2.30 \\
\hline $10 \mathrm{U}-10 \mathrm{Zr}-2 \mathrm{Nb}$ & -0.83 & -0.64 & -0.86 & -0.78 & -0.75 \\
\hline $15 \mathrm{U}-15 \mathrm{Zr}-3 \mathrm{Nb}$ & +0.18 & -1.00 & -0.95 & -1.20 & -1.23 \\
\hline $15 \mathrm{U}-7.5 \mathrm{Zr}-3 \mathrm{Nb}$ & -0.14 & -1.83 & -1.40 & -1.58 & -1.42 \\
\hline $20 \mathrm{U}-20 \mathrm{Zr}-4 \mathrm{Nb}$ & +0.18 & -0.48 & -0.65 & -0.95 & -1.01 \\
\hline $10 \mathrm{U}-2.5 \mathrm{Ce}$ & \multicolumn{3}{|c|}{ Disintegrated } & & \\
\hline $10 \mathrm{U}-10 \mathrm{Zr}-5.2 \mathrm{Ce}$ & -3.79 & -3.56 & -3.51 & \multicolumn{2}{|c|}{ Disintegrated } \\
\hline $10 \mathrm{U}-2 \mathrm{Y}$ & \multicolumn{2}{|c|}{ Disintegrated } & & & \\
\hline $10 \mathrm{U}-10 \mathrm{ZI}-2 \mathrm{Y}$ & -5.84 & -3.56 & -2.58 & \multicolumn{2}{|c|}{ Disintegrated } \\
\hline $10 \mathrm{U}-10 \mathrm{Zr}-5 \mathrm{Ti}$ & -1.57 & -1.36 & -1.42 & -1.34 & -1.27 \\
\hline $10 \mathrm{U}-10 \mathrm{Zr}-3.2 \mathrm{La}$ & -2.32 & -2.12 & -1.97 & -1.64 & -1.4 .1 \\
\hline $10 \mathrm{U}-10 \mathrm{Zr}-2 \mathrm{Ru}$ & -3.65 & -3.08 & -2.66 & -1.93 & -1.56 \\
\hline \multicolumn{6}{|c|}{ Heated $24 \mathrm{Hr}$ at $1000 \mathrm{C}$, Furnace Cooled } \\
\hline $10 \mathrm{U}-10 \mathrm{Zr}$ & -2.03 & -2.11 & -1.80 & -1.77 & Disintegrated \\
\hline $20 \mathrm{U}-20 \mathrm{Zr}$ & -0.06 & -1.05 & -1.08 & -1.23 & -1.22 \\
\hline $25 \mathrm{U}-25 \mathrm{Zr}$ & +0.08 & +0.02 & -0.42 & -0.74 & -0.79 \\
\hline $20 \mathrm{U}-10 \mathrm{Zr}-4 \mathrm{Nb}$ & +0.21 & -1.49 & -1.14 & -1.39 & -1.24 \\
\hline $15 \mathrm{U}-15 \mathrm{Zr}-3 \mathrm{Nb}$ & +0.15 & -1.30 & -1.10 & -1.32 & -1.24 \\
\hline $15 \mathrm{U}-7.5 \mathrm{Zr}-3 \mathrm{Nb}$ & -0.32 & -2.28 & -1.82 & -1.83 & Disintegrated \\
\hline $20 \mathrm{U}-20 \mathrm{Zr}-4 \mathrm{Nb}$ & -0.19 & -0.78 & -0.82 & -1.10 & Disintegrated \\
\hline $10 \mathrm{U}-2.5 \mathrm{Ce}$ & \multicolumn{2}{|c|}{ Disintegrated } & & & \\
\hline $10 \mathrm{U}-10 \mathrm{Zr}-5.2 \mathrm{Ce}$ & -5.37 & -4.67 & -3.70 & -- & -- \\
\hline $10 U-2 \mathrm{Y}$ & \multicolumn{2}{|c|}{ Disintegrated } & & & \\
\hline $10 \mathrm{U}-10 \mathrm{Zr}-2 \mathrm{Y}$ & -2.16 & -2.12 & -2.08 & -1.79 & -- \\
\hline $10 \mathrm{U}-10 \mathrm{Zr}-5 \mathrm{Ti}$ & -2.62 & -2.64 & -2.54 & -2.14 & - \\
\hline $10 \mathrm{U}-10 \mathrm{Zr}-3.2 \mathrm{La}$ & -2.98 & -3.09 & -2.96 & \multicolumn{2}{|c|}{ Disintegrated } \\
\hline $10 \mathrm{U}-10 \mathrm{Zr}-2 \mathrm{Ru}$ & -2.94 & -2.52 & -4.48 & \multicolumn{2}{|c|}{ Disintegrated } \\
\hline
\end{tabular}


carbon content of the Ames thorium is reflected in slightly higher hardnesses at various stages of preparation, working, and heat treatment, and also in a higher rate of work hardening. However, the carbon loses its effectiveness as a hardening agent at elevated temperatures. The higher oxygen content of Ames thorium also is responsible for lower densities of thorium-uranium alloys as compared with alloys prepared from iodide thorium.

Casting technique has a pronounced effect on the microstructure of thoriumuranium alloys, the effect being attributable to the cooling rate which the alloys encounter during solidification. The microstructure of thorium-5 to $15 \mathrm{w} / 0$ uranium alloys consists of a random dispersion of uranium particles in a thorium matrix when the alloys are arc melted and cast on a cold, copper hearth. Induction-melted thorium-10 to $20 \mathrm{w} / 0$ uranium alloys, cast into carbon molds, exhibit grain-boundary deposits of uranium. The thorium-20 w/o uranium alloy contains grain-boundary deposits of uranium regardless of melting technique. While it is possible to more randomly distribute the uranium in the induction-melted alloys by quenching from $1000 \mathrm{C}$, complete randomization cannot be obtained since some particles remain in the grain boundaries.

Working of the induction-melted alloys results in stringering of the uranium phase to a greater degree than is apparent in the arc-melted alloys.

Casting technique has a slight effect on hardness of the alloys. In the as-cast state or hot-worked state, the arc-cast alloys are slightly harder due to retention of uranium in solution as a result of the higher cooling rate employed in casting. However fully recrystallized induction-melted alloys appear to be slightly harder as a result of zirconium and possibly oxygen pickup during melting in zirconia crucibles.

The temperature of recrystallization of thorium-uranium alloys is about $725 \mathrm{C}$ for 90 per cent cold-reduced material. This temperature is over $100 \mathrm{C}$ higher than the recrystallization temperature for thorium. At lower temperatures and for lower amounts of cold work, the alloys only undergo partial recrystallization and grain growth with the result that a duplex structure is produced. This behavior is attributed to the presence of the uranium particles which lead to nonuniform stress concentrations in the alloy during working.

From the viewpoint of irradiation behavior, it is deemed desirable to produce a thorium-uranium structure in which uranium particles are uniformly dispersed in the thorium matrix. This sets an upper limit of uranium concentration al about $15 \mathrm{w} / \mathrm{O}$ uranium, sincd the $20 \mathrm{w} / \mathrm{o}$ uranium alloy, regardless of casting method, contains uranium concentrations at the grain boundaries. In order to obtain a random dispersion of fine uranium particles such that fission-product damage and distribution during irradiation are uniform, a high cooling rate during casting, such as is achieved during arc casting, is desirable. While uranium particle sizes are generally smaller than the fission-product range regardless of the casting technique employed, the particles in the induction-melted alloys tend to be larger than those appearing in the arc-melted alloys. Also, when the uranium appears in the thorium grain boundaries, the fission-product range is usually exceeded at least in one direction. Since it may be difficult to achieve the high cooling rates necessary for a fine and random uranium dispersion during casting of large melts, quenching from elevated temperatures, while not producing quite as random a distribution, provides an alternate method for developing the desired uranium distribution. 
Ternary and Quaternary Thorium-Uranium Alloys

Thorium-uranium alloys containing additions of molybdenum and niobium or small amounts of zirconium and niobium exhibit microstructures fairly similar to their binary-alloy counterparts, although the uranium is present in the metastable gammauranium form. Zirconium additions exert a pronounced effect on the alloy structures, a wide variety of structures being obtained as the uranium and zirconium content and the heat treatment are varied. In alloys quenched from elevated temperatures, the uranium is present as a gamma solid solution. On slow cooling the gamma transforms to the intermediate uranium-zirconium delta phase. Niobium additions to the zirconium-containing alloys stabilize the gamma phase.

Ternary and quaternary additions to the thorium-uranium alloys have a significant effect on hot hardness. Zirconium additions increase hardness of the binary alloys considerably at temperatures up to $600 \mathrm{C}$. Above this temperature, alloys containing zirconium soften rapidly, although the hardness is still greater than that of corresponding binary alloys. Alloys containing molybdenum and niobium, on the other hand, are softer than the corresponding binaries at temperatures of $600 \mathrm{C}$ and below. However, while these alloys also soften above $600 \mathrm{C}$, the rate of softening wtih increasing temperature is much less than for the alloys containing zirconium, and these alloys also exhibit higher hardnesses than corresponding binary alloys at elevated temperatures.

On the basis of the corrosion studies performed, it is deemed impossible to increase the corrosion resistance of thorium uranium alloys to any significant extent by ternary or quaternary alloying of the alpha-thorium phase structure.

From the viewpoint of resistance to irradiation damage, two beneficial effects on thorium-uranium alloys may be realized by ternary and quaternary alloying. When alloyed with molybdenum and niobium, the metastable gamma-uranium phase is $x e-$ tained, the gamma phase being more resistant to radiation swelling than the alphauranium phase. If hot hardness is accepted as an indication of high-temperature strength, then alloying with molybdenum, niobium, and zirconium or niobium and zirconium should increase resistance of the alloys to swelling when irradiated at high temperatures.

Studies of these alloys are continuing.

\section{REFERENCES}

(1) Gates, J. E., Lamale, G. E., and Dickerson, R. F., "The Examination and Evaluation of Irradiated Thorium-11 w/o Uranium Specimens", BMI-1334 (April 16, 1959).

(2) Ivanov, O., and Badayeva, R., "Phase Diagrams of Certain Uranium and Thorium Systems", A./Conf./15/P/2043.

(3) Wilhelm, H. A., (Editor) The Metal Thorium, ASM (1958) p 268. 